\title{
Synthesis and Characterization of Photopolymerizable Liquid Crystalline Compounds Having Two Reactive Sites
}

\author{
Ki Suk Jang, Suk Hoon Kang, and Ji Young Chang* \\ Department of Materials Science and Engineering, and Hyperstnctured Organic Materials Research Center, \\ College of Engineering, Seonl National University, Seonl 151-744, Korea. "E-mail:jichang@smiac.kr \\ Received June 18, 2007
}

\begin{abstract}
Rod-like polymerizable LC molecules having two different reactive groups, i.e acryl and diacetylene groups were prepared. 4-IIydroxyphenyldiacetylenes were synthesized by the coupling reaction of 1-bromoalkynes with 4-ethynylphenol and then reacted with 4-(6-acryloyloxyalkyloxy)benzoic acid to give polymerizable LC molecules 4a-d. The mesomorphic properties of compounds $4 \mathbf{a}-\mathbf{d}$ were investigated by differential scanning calorimetry, polarized optical microscopy and X-ray diffractometry. Compounds 4a-c exhibited smectic and nematic phases, but compound $\mathbf{4 d}$ having a longest alkyl tail among the series formed only a smectic phase. Photopolymerizability of acryl and diacetylene groups was investigated by $\mathbb{R}$ spectroscopy. An anisotropic polymer film could be prepared by selective polymerization of acryl groups with $365 \mathrm{~nm}$ UV light in the presence of a photoinitiator (2,2-dimethoxy-2-phenylacetophenone). The subsequent reaction of diacetylene groups with $254 \mathrm{~nm}$ UV light disrupted the anisotropic structure, suggesting that these LC molecules could be used for imaging on the film.
\end{abstract}

Key Words : Polymerizable liquid crystal, Diacetylene, UV irradiation, Photopolymerization

\section{Introduction}

Photopolymerizable liquid crystal (LC) monomers are of great interest because of their potential applications in display and data storage industries. ${ }^{1-3}$ They can be macroscopically oriented under electric or magnetic fields, and on mechanically rubbed substrates. Their in-situ photopolymerization in the LC state produces an anisotropic film having an aligned structure of LC molecules. ${ }^{4-10}$

There are two general methods for preparing an LC monomer. Firstly vinyl groups can be attached to both sides of a mesogen through flexible spacers. In the second method, photoreactive groups are introduced into mesogens to become parts of rigid rods. We previously reported LC molecules having two chalcone units ${ }^{11.12}$ or two diacetylene groups $^{13}$ as parts of rigid rods. A chalcone is known to form a dimer by $[2+2]$ addition reaction when exposed to UV light. The polymerization of the LC molecules having two chalcone units proceeds in a stepwise manner. The polymerization of diacetylenes occurs topochemically via 1,4addition by irradiation ${ }^{1+17}$ Since theses molecules had two reactive sites within one structure, the photopolymerization in the LC state distupted an aligned structure, resulting in optical property changes. When the photopolymerization was carried out through a photomask, an excellent-patterned image was obtained.

In this work, we prepared rod-like LC molecules having two different photopolymerizable groups, i.e. acryl and diacetylene groups. We introduced an acryl group at one end of a mesogen through a flexible spacer and a phenyl diacetylene group as a part of rigid rod. Since two functional groups have different photoreactivity, we expected the selective reaction of each group, depending on irradiation conditions. We report here the synthesis and polymerization of heterobifunctional LC molecules.

\section{Experimental Section}

Measurements. ${ }^{1} \mathrm{H}$ and ${ }^{13} \mathrm{C}$ NMR spectra were recorded on a BRUKER Avance DPX-300 and Avance 500 spectrometer. FT-IR spectra were obtained with PERKIN ELMER Spectrum GX I using a $\mathrm{KBr}$ window. The differential scanning calorimetry (DSC) measurements were performed with a TA modulated DSC 2090. X-ray diffractograms were obtained by using a Mac Science M18XHF-SRA (Cu K radiation, $\lambda=1.54 \AA$ ). The optical microscopy study was performed using a Leica DM LP equipped with Mettler Toledo FP 82HT heating stage and Mettler Toledo FP 90 central process controllex. Elemental analysis was performed using a CE instrument EA 1110 analyzer.

Synthesis of 4-(6-Hydroxyhexyloxy)benzoic acid (1). 4Hydroxybenzoic acid ( $10 \mathrm{~g}, 72.40 \mathrm{mmol})$ was dissolved in a mixture of ethanol $(30 \mathrm{~mL})$ and water $(20 \mathrm{~mL})$ along with potassium hydroxide $(10.78 \mathrm{~g}, 192 \mathrm{mmol})$ and a pinch of potassium iodide. 1-Chloro-6-hydroxyhexane $(9.01 \mathrm{~g}, 66$ $\mathrm{mmol}$ ) was added slowly to the mixture at room temperature while stirring vigorously, and then the mixture was refluxed for $48 \mathrm{~h}$. After evaporation of the solvents, the solid residue was dissolved in water $(120 \mathrm{~mL})$ and washed with diethyl ether $(3 \times 30 \mathrm{~mL})$. The aqueous layer was acidified with concentrated $\mathrm{HCl}$ until the $\mathrm{pH}$ was 2 . The precipitates were isolated by filtration, washed with water, and recrystallized from ethanol to give compound 1 in $54 \%$ yield. ${ }^{1} \mathrm{H}$ NMR $\left(\mathrm{CDCl}_{3}, \mathrm{ppm}\right): \delta=8.08,6.95$ (dd, aromatic protons, $4 \mathrm{H}$ ), $4.20(\mathrm{~s},-\mathrm{OH}, 1 \mathrm{H}), 4.05\left(\mathrm{t},-\mathrm{OCH}_{2}, 2 \mathrm{H}\right), 1.87-1.48(\mathrm{~m}$, alkyl chain protons, $8 \mathrm{H}$ ). 
Synthesis of 4-(6-Acryloyloxyhexyloxy)benzoic Acid (2). Compound $1(5 \mathrm{~g}, 21.53 \mathrm{mmol})$, acrylic acid $(5.71 \mathrm{~mL}$, $83.3 \mathrm{mmol}), p$-toluene sulfonic acid $(1.40 \mathrm{~g}, 7.35 \mathrm{mmol})$, and hydroquinone $(0.47 \mathrm{~g}, 4.27 \mathrm{mmol})$ were dissolved in toluene. The solution was refluxed for $12 \mathrm{~h}$ in a flask equipped with a Dean-stark trap. After evaporation of the solvent, the residue was dissolved in chloroform $(40 \mathrm{~mL})$, diluted with diethyl ether $(200 \mathrm{~mL})$, and washed with warm water until no more acrylic acid was detected. The organic layer was dried over anhydrous $\mathrm{MgSO}_{4}$. After filtration and evaporation of the solvent, the solid residue was recrystallized from isopropanol to give compound 2 in $48 \%$ yield. ' $\mathrm{H}$ NMR $\left(\mathrm{CDCl}_{3}, \mathrm{ppm}\right): \delta=8.08,6.95$ (dd, aromatic protons, $4 \mathrm{H}), 6.45,6.19,5.86(\mathrm{~m}$, vinyl protons, $3 \mathrm{H}), 4.22,4.07$ (t, $-\mathrm{OCH}_{2}, 4 \mathrm{H}$ ), 1.87-1.46 (m, alkyl chain protons, $8 \mathrm{H}$ ).

Synthesis of Compound 3 . Compound 3 was prepared according to our previous report. ${ }^{13}$

Synthesis of Compound 4. A typical procedure is as follows. To compound $2(1.84 \mathrm{~g}, 6.32 \mathrm{mmol})$ were added thionyl chloride $(2.79 \mathrm{~g}, 23.48 \mathrm{mmol}), 2,6$-di-t-butyl 4methylphenol $(0.44 \mathrm{~g}, 1.99 \mathrm{mmol})$ as an inhibitor, and a catalytic amount of dimethylformamide (DMF) (two drops). After stirring for $40 \mathrm{~min}$, the excess thionyl chloride was removed under reduced pressure. The residue was dissolved in chloroform $(8 \mathrm{~mL})$, and to the solution was added dropwise a solution of compound $3(n=5)(1.10 \mathrm{~g}, 4.86$ $\mathrm{mmol})$ and triethylamine $(0.54 \mathrm{~g}, 5.35 \mathrm{mmol})$ in chloroform $(15 \mathrm{~mL})$ at $0^{\circ} \mathrm{C}$. After stirring for $16 \mathrm{~h}$ at room temperature, chloroform $(100 \mathrm{~mL})$ was added to the mixture and the resulting solution was washed with water $(30 \mathrm{~mL}), 2 N$ sodium hydroxide $(3 \times 60 \mathrm{~mL})$, and water $(2 \times 40 \mathrm{~mL})$. The organic layer was dried over anhydrous $\mathrm{MgSO}_{4}$. After filtration and evaporation of the solvent, the product was isolated by column chromatography on silica gel $(20 \%$ ethyl acetate in hexane) and further purified by recrystallization from ethanol to give compound $\mathbf{4 b}$ in $41 \%$ yield. ${ }^{1} \mathrm{H}$ NMR (DMSO-d 6, ppm): $\delta=8.07,7.63,7.32,7.12$ (ddd, aromatic protons, $8 \mathrm{H}$ ), 6.33, 6.22, 5.96 (m, vinyl protons, $3 \mathrm{H}$ ), 4.14 (m, $\left.-\mathrm{OCH}_{2}, 4 \mathrm{H}\right), 2.46\left(\mathrm{t}, \mathrm{CCH}_{2}, 2 \mathrm{H}\right), 1.62-1.22(\mathrm{~m}$, alkyl chain protons, $16 \mathrm{H}), 0.89\left(\mathrm{t},-\mathrm{CH}_{3}, 3 \mathrm{H}\right) . \mathrm{R}\left(\mathrm{KBr}, \mathrm{cm}^{-1}\right)$ : $2935,2860,2244,2145,1739,1719,1636,1608,1408,989$, $879,844,814 .{ }^{13} \mathrm{C}$ NMR $\left(\mathrm{CDCl}_{3}, \mathrm{ppm}\right): \delta=166.5,164.7$, $163.8,151.6,134.0,133.8,132.6,132.5,130.2,128.5$, $122.3,122.1,121.5,119.8,114.6,114.5,85.2,74.7,74.2$, $68.3,65.2,64.7,31.5,29.8,29.2,28.8,28.6,28.4,25.9,22.7$, 19.5, 13.8. Anal. Calcd for $\mathrm{C}_{32} \mathrm{H}_{36} \mathrm{O}_{5}: \mathrm{C}, 76.77 ; \mathrm{H}, 7.25$. Found: C, 76.75; H, 7.32.

For 4a: Yield, 53\%. 'H NMR (DMSO- $d_{6,}$, ppm): $\delta=8.07$, $7.64,7.33,7.12$ (dddd, aromatic protons, $8 \mathrm{H}$ ), 6.32, 6.20, $5.88(\mathrm{~m}$, vinyl protons, $3 \mathrm{H}), 4.11\left(\mathrm{~m},-\mathrm{OCH}_{2}, 4 \mathrm{H}\right), 2.43(\mathrm{t}$, $\mathrm{CCH}_{2}, 2 \mathrm{H}$ ), $1.51-1.38$ (m, alkyl chain protons, $\left.12 \mathrm{H}\right), 0.92$ (t, $\left.-\mathrm{CH}_{3}, 3 \mathrm{H}\right)$. IR $\left(\mathrm{KBr}, \mathrm{cm}^{-1}\right): 2958,2865,2242,2148,1744$, $1713,1636,1600,1409,1006,987,875,851,814,805 .{ }^{13} \mathrm{C}$ NMR $\left(\mathrm{CDCl}_{3}, \mathrm{ppm}\right): \delta=166.5,164.7,163.8,151.6,134.0$, $133.8,132.6,132.5,130.2,128.5,122.4,122.3,121.7$, $120.0,114.9,114.6,85.2,74.7,74.2,68.3,65.3,64.7,30.5$, $29.8,29.2,28.8,25.9,22.2,19.5,13.8$. Anal. Calcd for
$\mathrm{C}_{30} \mathrm{H}_{32} \mathrm{O}_{5}: \mathrm{C}, 76.25 ; \mathrm{H}, 6.83$. Found: $\mathrm{C}, 75.94 ; \mathrm{H}, 6.82$.

For $4 \mathrm{c}$ : Yield, $48 \% .{ }^{1} \mathrm{H}$ NMR (DMSO- $d_{6,}$, ppm): $\delta=7.96$, $7.53,7.22,7.02$ (dddd, aromatic protons, $8 \mathrm{H}$ ), 6.19, 6.11, $5.85(\mathrm{~m}$, vinyl protons, $3 \mathrm{H}), 4.03\left(\mathrm{~m},-\mathrm{OCH}_{2}, 4 \mathrm{H}\right), 2.34(\mathrm{t}$, $\mathrm{CCH}_{2}, 2 \mathrm{H}$ ), 1.64-1.15 (m, alkyl chain protons, $20 \mathrm{H}$ ), 0.76 (t, $\left.-\mathrm{CH}_{3}, 3 \mathrm{H}\right) . \mathrm{IR}\left(\mathrm{KBr}, \mathrm{cm}^{-1}\right): 2931,2854,2243,2145,1737$, $1723,1635,1606,1408,1000,985,875,844,811 .{ }^{13} \mathrm{C} \mathrm{NMR}$ $\left(\mathrm{CDCl}_{3}, \mathrm{ppm}\right): \delta=166.5,164.7,163.8,151.6,134.0,133.8$, $132.6,132.5,130.2,128.5,122.4,122.1,121.4,119.8,114.8$, $114.6,85.2,74.7,74.2,68.3,65.2,64.7,32.1,29.7,29.4$, $29.3,29.2,29.1,28.8,28.5,25.9,22.9,19.8,14.3$. Anal. Calcd for $\mathrm{C}_{34} \mathrm{H}_{40} \mathrm{O}: \mathrm{C}, 77.24 ; \mathrm{H}, 7.63$. Found: $\mathrm{C}, 77.25 ; \mathrm{H}$, 7.66.

For 4 d. Yield, $47 \% .{ }^{1} \mathrm{H}$ NMR (DMSO- $d_{5,}$ ppm): $\delta=8.07$, $7.64,7.32,7.12$ (dddd, aromatic protons, $8 \mathrm{H}$ ), 6.30, 6.21, $5.95(\mathrm{~m}$, vinyl protons, $3 \mathrm{H}), 4.13\left(\mathrm{~m},-\mathrm{OCH}_{2}, 4 \mathrm{H}\right), 2.44(\mathrm{t}$, $\mathrm{CCH}_{2}, 2 \mathrm{H}$ ), 1.75-1.33 (m, alkyl chain protons, $24 \mathrm{H}$ ), 0.88 (t, $\left.-\mathrm{CH}_{3}, 3 \mathrm{H}\right)$. IR $\left(\mathrm{KBr}, \mathrm{cm}^{-1}\right): 2924,2854,2244,2144,1742$, $1721,1634,1602,1409,1006,990,875,853,813,802 .{ }^{13} \mathrm{C}$ NMR ( $\left.\mathrm{CDCl}_{3}, \mathrm{ppm}\right): \delta=166.5,164.7,163.8,151.6,134.0$, $133.8,132.6,132.5,130.2,128.5,122.3,122.1,121.4$, $119.8,114.6,114.5,85.2,74.7,74.2,68.3,65.2,64.7,32.1$, $29.8,29.7,29.6,29.5,29.3,29.2,29.1,28.8,28.5,25.9,22.9$, 19.8, 14.3. Anal. Caled for $\mathrm{C}_{36} \mathrm{H}_{44} \mathrm{O}_{5}: \mathrm{C}, 77.66 ; \mathrm{H}, 7.97$. Found: C, $77.77 ; \mathrm{H}, 8.00$.

Radical Polymerization of Compound $4 \mathrm{~b}$. In a $10 \mathrm{~mL}$ polymerization tube, compound $4 \mathrm{~b}(0.3 \mathrm{~g}, 0.56 \mathrm{mmol})$ and AIBN $(0.0046 \mathrm{~g}, 0.028 \mathrm{mmol})$ were dissolved in dry THF (3 $\mathrm{ml}$ ). The reaction mixture was degassed by a freeze-thaw method to remove oxygen. After sealing the ample, the mixture was heated with stirring at $60^{\circ} \mathrm{C}$ for $48 \mathrm{~h}$. The polymer was isolated and dropped into $n$-hexane to precipitate the polymer. The polymer was dried for $24 \mathrm{~h}$ in vacuum oven. Yield, $36.7 \%$. ${ }^{1} \mathrm{H} \mathrm{NMR}\left(\mathrm{CDCl}_{3}, 300 \mathrm{MHz}\right): \delta$ $=8.15-6.9(8 \mathrm{H}, \mathrm{Ar}-\mathrm{H}), 4.22-2.35\left(6 \mathrm{H},-\mathrm{OCH}_{2}, \mathrm{CCH}_{2}\right), 1.82-$ $1.25(\mathrm{~m}, 19 \mathrm{H}$, polymer backbone and alkyl chain protons), $0.83\left(3 \mathrm{H},-\mathrm{CH}_{3}\right)$.

\section{Results and Discussion}

Synthesis of Polymerizable Mesogens. The rod-like mesogenic monomers were prepared according to Scheme 1. 4-Hydroxybenzoic acid was reacted with 6-chlorohexanol to yield compound 1. An acryl group was introduced to compound 1 by esterification reaction with acrylic acid. The carboxyl end group of acryl compound 2 was converted to acid chloride with thionyl chloride and then reacted with 4-hydroxyphenyldiacetylenes 3 , which were synthesized by the coupling reaction of 1-bromoalkynes with 4-ethynylphenol, to give compounds 4a-d. The structures of all products were identified by ${ }^{1} \mathrm{H}$ and ${ }^{13} \mathrm{C}$ NMR spectroscopy, IR spectroscopy, and elemental analysis.

Mesomorphic Properties. The mesomorphic properties of compounds 4a-d were investigated by DSC, polarized optical microscopy (POM) and X-ray diffractometry. The compounds showed enantiotropic transitions. In the DSC study, sharp phase transitions were observed upon heating 
<smiles>O=C(O)c1ccc(O)cc1</smiles>

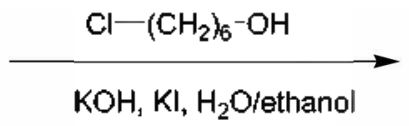<smiles>O=C(O)c1ccc(OCCOO)cc1</smiles><smiles>C=CC(=O)O</smiles>

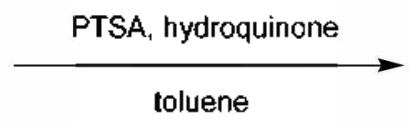<smiles>C=CC(=O)OCCOc1ccc(C(=O)O)cc1</smiles>

2<smiles>CCCC#C[C+]#Cc1ccc(O)cc1</smiles><smiles>CNCCC#CC#Cc1ccc(O)cc1</smiles>

3<smiles>C=CC(=O)OCCOc1ccc(C(=O)Cl)cc1</smiles>

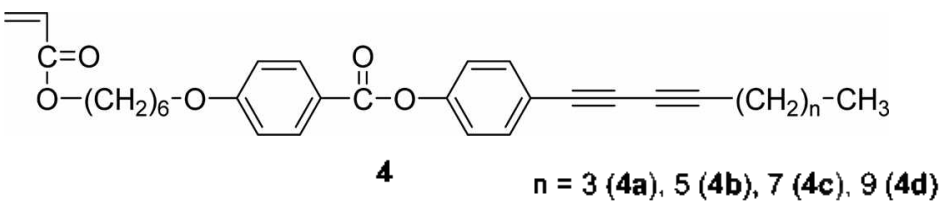

Scheme 1

and cooling with a scan rate of $5^{\circ} \mathrm{C} / \mathrm{min}$. For example, compound $4 \mathrm{~b}$ showed three endothermic peaks at $55.4^{\circ} \mathrm{C}$ $(\Delta H=31.5 \mathrm{~kJ} / \mathrm{mol}), 79.7^{\circ} \mathrm{C}(\Delta H=1.67 \mathrm{~kJ} / \mathrm{mol})$, and $86.1^{\circ} \mathrm{C}$ ( $\Delta H=0.38 \mathrm{~kJ} / \mathrm{mol}$ ) during the $2^{\text {nd }}$ heating, and three exothermic peaks at $84.8{ }^{\circ} \mathrm{C}(\Delta H=0.76 \mathrm{~kJ} / \mathrm{mol}), 78.4{ }^{\circ} \mathrm{C}$ $(\Delta H=1.66 \mathrm{~kJ} / \mathrm{mol})$, and $3.7^{\circ} \mathrm{C}(\Delta H=20.6 \mathrm{~kJ} / \mathrm{mol})$ during

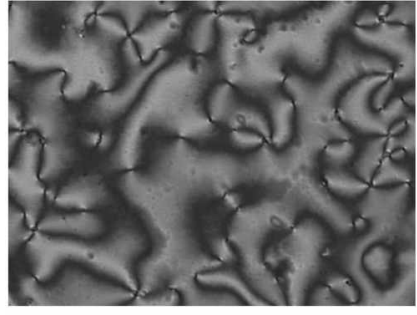

(a)

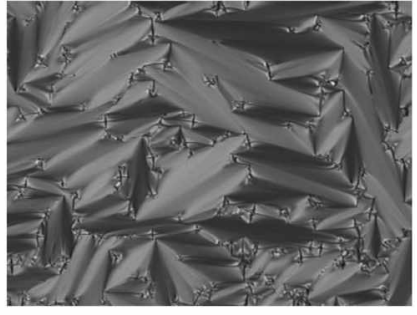

(b)
Figure 1. Polarizing optical micrographs of $4 \mathrm{~b}$ taken (a) at $83^{\circ} \mathrm{C}$ and (b) at $50^{\circ} \mathrm{C}$ on cooling. the $2^{\text {nd }}$ cooling. In POM analysis, a focal conic fan-type texture appeared from $55.4^{\circ} \mathrm{C}$ and then a Schlieren texture above $79.7^{\circ} \mathrm{C}$ on heating, corresponding to a smectic and a nematic phase, respectively (Figure 1). The same textures were observed on cooling. Compounds $4 a$ and $4 \mathbf{c}$ also exhibited two LC phases, but compound $4 \mathbf{d}$ having a longest alkyl tail among the series formed only a smectic phase. The thermal transitions of $\mathbf{4 a -} \mathbf{d}$ are summarized in Table 1.

The structures of the smectic phases of $\mathbf{4 a - 4 d}$ were further investigated by using an $\mathrm{X}$-ray diffraction technique. Figure 2 shows the X-ray diffractogram of $4 \mathrm{~b}$ measured at $50^{\circ} \mathrm{C}$. In the small-angle region, three sharp peaks with $d$ spacings of $35.9,17.8$, and $11.8 \AA$ appeared, corresponding to the (100), $(200)$, and $(300)$ Bragg reflections, respectively. Since the length of the molecule was calculated to be $35.7 \AA$, which was almost the same as the (100) spacing of $35.9 \AA$, it seems that the compound had a monolayered smectic A structure. Other compounds also showed similar results. The X-ray

Table 1. Phase transition temperatures $\left({ }^{\circ} \mathrm{C}\right.$ ) and enthalpy values (in parentheses, $\mathrm{kJ} / \mathrm{mol}$ ) of compounds $4 \mathrm{a}-\mathrm{d}$ determined by DSC at a rate of $5^{\circ} \mathrm{C} \mathrm{min}{ }^{-1}$

\begin{tabular}{ccc}
\hline Compound & $2^{\text {nd }}$ heating & $2^{\text {nd }}$ cooling \\
\hline $\mathbf{4 a}$ & $\mathrm{K} 63.8(33.1) \mathrm{Sm} 83.8(4.36) \mathrm{N} 92.1(0.77) \mathrm{J}$ & $\mathrm{I} 91.7(0.60) \mathrm{N} 83.3(2.16) \mathrm{Sm} 27.2(19.5) \mathrm{K}$ \\
$\mathbf{4 b}$ & $\mathrm{K} 55.4(31.5) \mathrm{Sm} 79.7(1.67) \mathrm{N} 86.1(0.38) \mathrm{J}$ & $\mathrm{J} 84.8(0.76) \mathrm{N} 78.4(1.66) \mathrm{Sm} 3.7(20.6) \mathrm{K}$ \\
$\mathbf{4} \mathbf{c}$ & $\mathrm{K} 21.2(0.8) \mathrm{Sm} 81.5(3.37) \mathrm{N} 84.8(0.95) \mathrm{I}$ & $\mathrm{I} 83.0(0.89) \mathrm{N} 80.0(1.86) \mathrm{Sm}-11.5(0.6) \mathrm{K}$ \\
$\mathbf{4 d}$ & $\mathrm{K} 47.7(26.3) \mathrm{Sm} 82.4(8.27) \mathrm{I}$ & $\mathrm{I} 80.3(7.90) \mathrm{Sm}-6.6(20.4) \mathrm{K}$ \\
\hline
\end{tabular}

${ }^{a} \mathrm{~K}=$ crystal; $\mathrm{Sm}=$ smectic; $\mathrm{N}=$ nemalic; $\mathrm{I}=$ isotropic. 


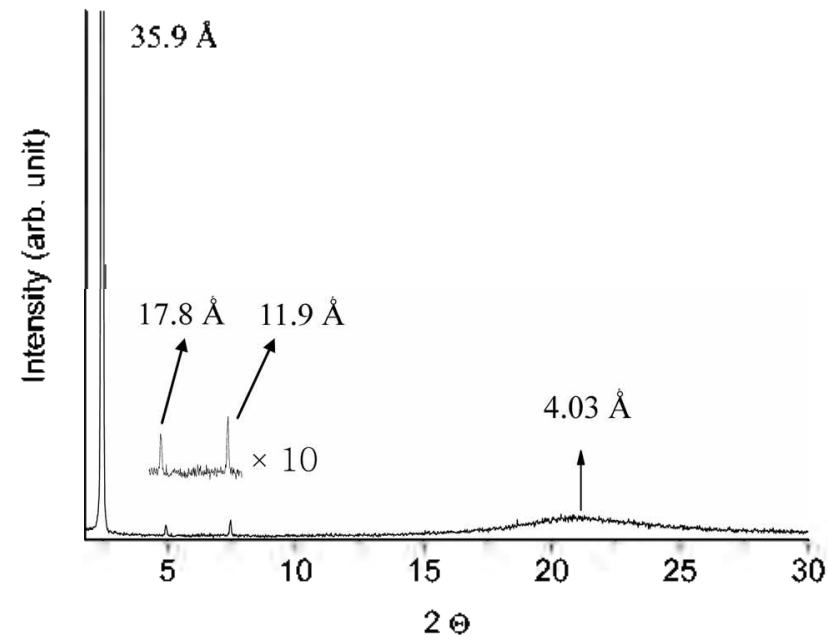

Figure 2. X-ray diffractogram of compound $\mathbf{4 b}$, obtained at $50^{\circ} \mathrm{C}$.

Table 2. X-ray diffraction data of the smectic phases of compounds 4a-d obtained at $50^{\circ} \mathrm{C}$

\begin{tabular}{|c|c|c|c|}
\hline Compound & $d_{c x^{\prime} j^{\prime}}(\AA)^{\prime \prime}$ & $d_{c u t c}(\mathrm{~A})^{\prime}$ & $(h k l)$ \\
\hline \multirow[t]{3}{*}{$4 a$} & 33.2 & 33.5 & $(100)$ \\
\hline & 16.5 & 16.7 & $(200)$ \\
\hline & 10.9 & 11.1 & $(300)$ \\
\hline \multirow[t]{3}{*}{$4 b$} & 35.9 & 35.7 & $(100)$ \\
\hline & 17.8 & 17.8 & $(200)$ \\
\hline & 11.8 & 11.9 & $(300)$ \\
\hline \multirow[t]{3}{*}{$4 c$} & 38.7 & 38.3 & $(100)$ \\
\hline & 18.8 & 19.1 & $(200)$ \\
\hline & 12.6 & 12.7 & $(300)$ \\
\hline \multirow[t]{3}{*}{$4 d$} & 40.9 & 40.9 & $(100)$ \\
\hline & 21.5 & 20.5 & $(200)$ \\
\hline & 14.2 & 13.7 & $(300)$ \\
\hline
\end{tabular}

"Observed from XRD analysis. "Estimated from an extended molecular model.

diffraction data are summarized in Table 2 .

Photopolymerization. Photopolymerizability of an acryl and a diacetylene groups was investigated by IR spectroscopy. A solution of $4 \mathrm{~b}(0.1 \mathrm{~g})$ and a photoinitiator $(2,2-$ dimethoxy-2-phenylacetophenone, $4 \mathrm{wt} \%)$ in toluene $(0.4$ $\mathrm{mL}$ ) was cast on a $\mathrm{KBr}$ window, dried in vacuo, and sheared with a cover glass at $50^{\circ} \mathrm{C}$. The sample was first irradiated with $365 \mathrm{~nm}$ UV light $\left(1 \mathrm{~mW} / \mathrm{cm}^{2}\right)$. The IR band intensity at $1636 \mathrm{~cm}^{-1}$ for $\mathrm{C}=\mathrm{C}$ stretching of a vinyl group gradually decreased with increasing irradiation time, while the intensity of the band at $2241 \mathrm{~cm}^{-1}$ for a diacetylene group changed little, indicating the selective polymerization of the vinyl group (Figure 3). When irradiated with $254 \mathrm{~nm} \mathrm{UV}$ light $\left(3 \mathrm{~mW} / \mathrm{cm}^{2}\right)$, the diacetylene group was polymerized, resulting in a decrease in the intensity of the band at 2241 $\mathrm{cm}^{-1}$. Figure 4 shows a polar plot of the absorbance of the IR peak at $1731 \mathrm{~cm}^{-1}$ versus polarization angle. After shearing in the LC state, the molecules were oriented mostly parallel to the shearing direction. The oriented LC structure was maintained when about $50 \%$ of vinyl groups were polymerized by irradiation with $365 \mathrm{~nm}$ UV light. The
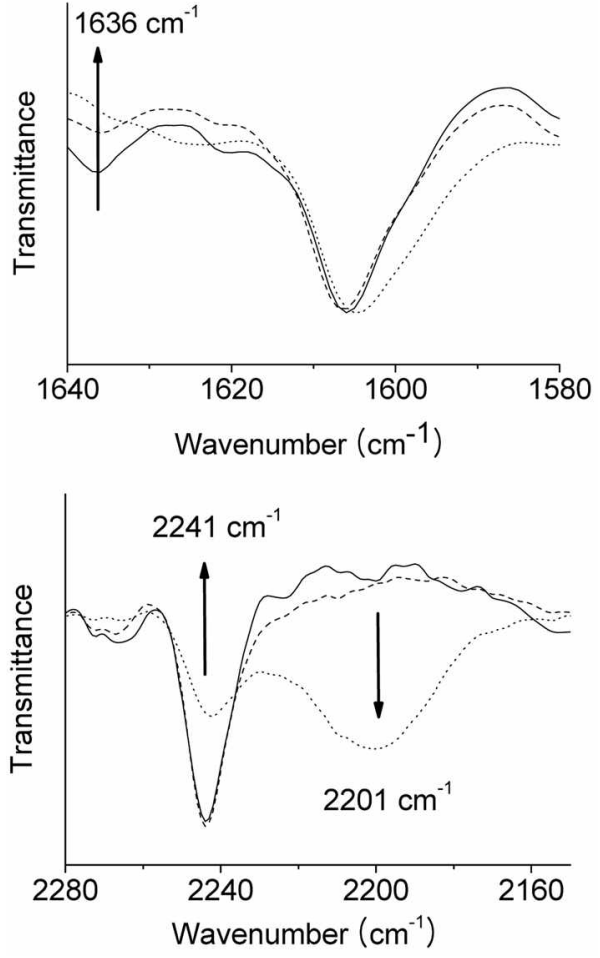

Figure 3. FT-IR spectral changes of compound $\mathbf{4 b}$ : before UV irradiation (solid line), after $365 \mathrm{~nm}$ UV irradiation for $10 \mathrm{~min}$ (dashed line), and after 365 nin UV irradiation for 10 min and 254 nur UV irradiation for 60 unin (dotted line).

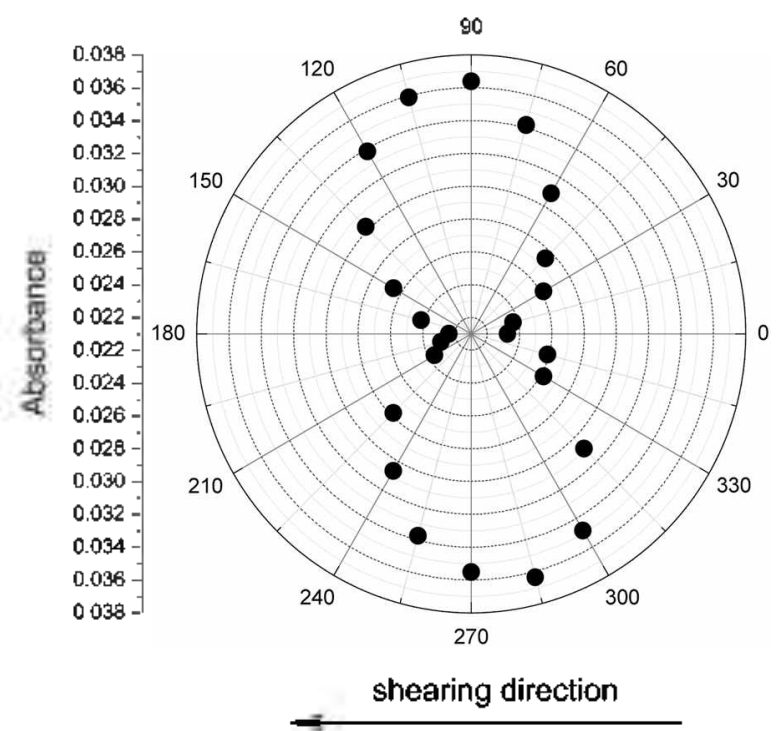

Figure 4. Polar plot of the absorbance of the $I R$ peak for the $C=O$ stretch at $1731 \mathrm{~cm}^{-1}$ versus polarization angle for $4 \mathbf{b}$.

aligned structure was disrupted by irradiation with $254 \mathrm{~nm}$ UV light, which caused cross-linking.

Radical Polymerization. The acryl group of compound 4b could be radically polymerized by initiation with AIBN in THF at $60^{\circ} \mathrm{C}$. Number average molecular weight and weight average molecular weight of the polymer measured by GPC were 7000 and 9790 , respectively. The polymer formed a smectic phase. In DSC analysis, an endothermic 
peak corresponding to isotropization was observed at 96.0 ${ }^{\circ} \mathrm{C}$ on $2^{\text {nd }}$ heating. On cooling, a weak exothermic peak appeared at $92.0^{\circ} \mathrm{C}$. A birefringent phase began to form at $92.0^{\circ} \mathrm{C}$ and persisted to room temperature. In the X-ray diffractogram, a relatively sharp peak with $d$ spacing of 35.2 $\AA$ appeared. We examined the miscibility of $4 \mathrm{~b}$ and the acryl polymer by POM. The $7: 3$ mixture of $4 \mathrm{~b}$ and the polymer showed isotropization at $94^{\circ} \mathrm{C}$. On cooling from the isotropic state with a rate of $5^{\circ} \mathrm{C} / \mathrm{min}$, however, phase separation occurred. This result is in contrast to the observation that the $\mathrm{LC}$ structure was maintained during in-situ polymerization of the vinyl group with $365 \mathrm{~nm}$ UV light in the LC state.

In summary, we prepared LC molecules having two different photopolymerizable groups, i.e. an acryl and a diacetylene group and examined their photoreactivity. An anisotropic polymer film could be prepared by selective polymerization of the acryl group with $365 \mathrm{~nm}$ UV light in the presence of a photoinitiator. The subsequent reaction of diacetylene groups with $254 \mathrm{~nm}$ UV light disrupted the anisotropic structure, suggesting that these LC molecules could be used for imaging on the film.

Acknowledgement. Financial support from the Korea Science and Engineering Foundation, through the Hyperstructured Organic Materials Center is gratefully acknowledged.

\section{References}

I. Broer, D. J.; Mol, G. N. Makronol. Chem. 1989, J90, 19.

2. Ichimura, K. Chem. Rev. 2000, 100, 1847.

3. Yoshio, M.; Kagata, T.; Hoshino, K.; Mukai, T.; Ohno, H.; Kato, T. J. Am. Chem. Soc, 2006, $128,5570$.

4. Penterman, R.; Klink, S. J.; de Koning, H.; Nisato, G.; Broer, D. J. Nafure 2002, 417,55,

5. Kondo, M.; Yu, Y.; Ikeda, T. Angew: Chem., Int. Ed. 2006, 45, 1378.

6. Ree, M. Macronol. Res. 2006, 14, 1 .

7. Baxter, B. C.; Gin, D. L. Macromolecules 1998, 3I, 4419.

8. Hoag, B. P.; Gin, D. L. Macromolecules $2000,33,8549$.

9. Vlachos, P; Kelly, S. M.; Mansoor, B.; ÓNeill, M. Chem. Commun 2002, 874.

10. Beyer, P.; Krueger, M.; Giesselmann, F.; Zentel, R. Adv: Funct. Mater. 2007, 17, 109 .

11. Chang, J. Y.; Nam, S. W.; Hong, C. G.; Im, J.-H.; Kim, J.-H.; Han, M. J. Adv. Mater, 2001, 13, 1298 .

12. Nam, S. W,; Kang, S. H.; Chang, J. Y. Macromol. Res. 2007, 15, 74.

13. Cho, H. J.; Seo, K.; Lee, C. J.; Yun, H.; Chang, J. Y. J. Mater. Chem. 2003, 13,986.

14. Lee, C. J.; Lee, S. J.; Chang, J. Y. Tetrahedron Lett. 2002, 43, 3863 .

15. Hwang, I. H.; Lee, S. J.; Chang, J. Y. J. Polym. Sci, Polym. Chem. Ed. 2003, 41, 1881 .

16. Chang. J. Y;; Baik, J. H.; Lee, C. B.; Han, M. J.; Hong, S.-K. J. An. Chent. Soc. 1997, 119, 3197.

17. Chang. J. Y.; Yeon, J. R.; Shin, Y. S.; Han, M. J.; Hong, S.-K. Chem. Mater, 2000, 12, 1076. 


\title{
Synthesis and Characterization of Photopolymerizable Liquid Crystalline Compounds Having Two Reactive Sites
}

\author{
Ki Suk Jang, Suk Hoon Kang, and Ji Young Chang* \\ Department of Materials Science and Engineering, and Hyperstnctured Organic Materials Research Center, \\ College of Engineering, Seonl National University, Seonl 151-744, Korea. "E-mail:jichang@smiac.kr \\ Received June 18, 2007
}

\begin{abstract}
Rod-like polymerizable LC molecules having two different reactive groups, i.e acryl and diacetylene groups were prepared. 4-IIydroxyphenyldiacetylenes were synthesized by the coupling reaction of 1-bromoalkynes with 4-ethynylphenol and then reacted with 4-(6-acryloyloxyalkyloxy)benzoic acid to give polymerizable LC molecules 4a-d. The mesomorphic properties of compounds $4 \mathbf{a}-\mathbf{d}$ were investigated by differential scanning calorimetry, polarized optical microscopy and X-ray diffractometry. Compounds 4a-c exhibited smectic and nematic phases, but compound $\mathbf{4 d}$ having a longest alkyl tail among the series formed only a smectic phase. Photopolymerizability of acryl and diacetylene groups was investigated by $\mathbb{R}$ spectroscopy. An anisotropic polymer film could be prepared by selective polymerization of acryl groups with $365 \mathrm{~nm}$ UV light in the presence of a photoinitiator (2,2-dimethoxy-2-phenylacetophenone). The subsequent reaction of diacetylene groups with $254 \mathrm{~nm}$ UV light disrupted the anisotropic structure, suggesting that these LC molecules could be used for imaging on the film.
\end{abstract}

Key Words : Polymerizable liquid crystal, Diacetylene, UV irradiation, Photopolymerization

\section{Introduction}

Photopolymerizable liquid crystal (LC) monomers are of great interest because of their potential applications in display and data storage industries. ${ }^{1-3}$ They can be macroscopically oriented under electric or magnetic fields, and on mechanically rubbed substrates. Their in-situ photopolymerization in the LC state produces an anisotropic film having an aligned structure of LC molecules. ${ }^{4-10}$

There are two general methods for preparing an LC monomer. Firstly vinyl groups can be attached to both sides of a mesogen through flexible spacers. In the second method, photoreactive groups are introduced into mesogens to become parts of rigid rods. We previously reported LC molecules having two chalcone units ${ }^{11.12}$ or two diacetylene groups $^{13}$ as parts of rigid rods. A chalcone is known to form a dimer by $[2+2]$ addition reaction when exposed to UV light. The polymerization of the LC molecules having two chalcone units proceeds in a stepwise manner. The polymerization of diacetylenes occurs topochemically via 1,4addition by irradiation ${ }^{1+17}$ Since theses molecules had two reactive sites within one structure, the photopolymerization in the LC state distupted an aligned structure, resulting in optical property changes. When the photopolymerization was carried out through a photomask, an excellent-patterned image was obtained.

In this work, we prepared rod-like LC molecules having two different photopolymerizable groups, i.e. acryl and diacetylene groups. We introduced an acryl group at one end of a mesogen through a flexible spacer and a phenyl diacetylene group as a part of rigid rod. Since two functional groups have different photoreactivity, we expected the selective reaction of each group, depending on irradiation conditions. We report here the synthesis and polymerization of heterobifunctional LC molecules.

\section{Experimental Section}

Measurements. ${ }^{1} \mathrm{H}$ and ${ }^{13} \mathrm{C}$ NMR spectra were recorded on a BRUKER Avance DPX-300 and Avance 500 spectrometer. FT-IR spectra were obtained with PERKIN ELMER Spectrum GX I using a $\mathrm{KBr}$ window. The differential scanning calorimetry (DSC) measurements were performed with a TA modulated DSC 2090. X-ray diffractograms were obtained by using a Mac Science M18XHF-SRA (Cu K radiation, $\lambda=1.54 \AA$ ). The optical microscopy study was performed using a Leica DM LP equipped with Mettler Toledo FP 82HT heating stage and Mettler Toledo FP 90 central process controllex. Elemental analysis was performed using a CE instrument EA 1110 analyzer.

Synthesis of 4-(6-Hydroxyhexyloxy)benzoic acid (1). 4Hydroxybenzoic acid ( $10 \mathrm{~g}, 72.40 \mathrm{mmol})$ was dissolved in a mixture of ethanol $(30 \mathrm{~mL})$ and water $(20 \mathrm{~mL})$ along with potassium hydroxide $(10.78 \mathrm{~g}, 192 \mathrm{mmol})$ and a pinch of potassium iodide. 1-Chloro-6-hydroxyhexane $(9.01 \mathrm{~g}, 66$ $\mathrm{mmol}$ ) was added slowly to the mixture at room temperature while stirring vigorously, and then the mixture was refluxed for $48 \mathrm{~h}$. After evaporation of the solvents, the solid residue was dissolved in water $(120 \mathrm{~mL})$ and washed with diethyl ether $(3 \times 30 \mathrm{~mL})$. The aqueous layer was acidified with concentrated $\mathrm{HCl}$ until the $\mathrm{pH}$ was 2 . The precipitates were isolated by filtration, washed with water, and recrystallized from ethanol to give compound 1 in $54 \%$ yield. ${ }^{1} \mathrm{H}$ NMR $\left(\mathrm{CDCl}_{3}, \mathrm{ppm}\right): \delta=8.08,6.95$ (dd, aromatic protons, $4 \mathrm{H}$ ), $4.20(\mathrm{~s},-\mathrm{OH}, 1 \mathrm{H}), 4.05\left(\mathrm{t},-\mathrm{OCH}_{2}, 2 \mathrm{H}\right), 1.87-1.48(\mathrm{~m}$, alkyl chain protons, $8 \mathrm{H}$ ). 
Synthesis of 4-(6-Acryloyloxyhexyloxy)benzoic Acid (2). Compound $1(5 \mathrm{~g}, 21.53 \mathrm{mmol})$, acrylic acid $(5.71 \mathrm{~mL}$, $83.3 \mathrm{mmol}), p$-toluene sulfonic acid $(1.40 \mathrm{~g}, 7.35 \mathrm{mmol})$, and hydroquinone $(0.47 \mathrm{~g}, 4.27 \mathrm{mmol})$ were dissolved in toluene. The solution was refluxed for $12 \mathrm{~h}$ in a flask equipped with a Dean-stark trap. After evaporation of the solvent, the residue was dissolved in chloroform $(40 \mathrm{~mL})$, diluted with diethyl ether $(200 \mathrm{~mL})$, and washed with warm water until no more acrylic acid was detected. The organic layer was dried over anhydrous $\mathrm{MgSO}_{4}$. After filtration and evaporation of the solvent, the solid residue was recrystallized from isopropanol to give compound 2 in $48 \%$ yield. ' $\mathrm{H}$ NMR $\left(\mathrm{CDCl}_{3}, \mathrm{ppm}\right): \delta=8.08,6.95$ (dd, aromatic protons, $4 \mathrm{H}), 6.45,6.19,5.86(\mathrm{~m}$, vinyl protons, $3 \mathrm{H}), 4.22,4.07$ (t, $-\mathrm{OCH}_{2}, 4 \mathrm{H}$ ), 1.87-1.46 (m, alkyl chain protons, $8 \mathrm{H}$ ).

Synthesis of Compound 3 . Compound 3 was prepared according to our previous report. ${ }^{13}$

Synthesis of Compound 4. A typical procedure is as follows. To compound $2(1.84 \mathrm{~g}, 6.32 \mathrm{mmol})$ were added thionyl chloride $(2.79 \mathrm{~g}, 23.48 \mathrm{mmol}), 2,6$-di-t-butyl 4methylphenol $(0.44 \mathrm{~g}, 1.99 \mathrm{mmol})$ as an inhibitor, and a catalytic amount of dimethylformamide (DMF) (two drops). After stirring for $40 \mathrm{~min}$, the excess thionyl chloride was removed under reduced pressure. The residue was dissolved in chloroform $(8 \mathrm{~mL})$, and to the solution was added dropwise a solution of compound $3(n=5)(1.10 \mathrm{~g}, 4.86$ $\mathrm{mmol})$ and triethylamine $(0.54 \mathrm{~g}, 5.35 \mathrm{mmol})$ in chloroform $(15 \mathrm{~mL})$ at $0^{\circ} \mathrm{C}$. After stirring for $16 \mathrm{~h}$ at room temperature, chloroform $(100 \mathrm{~mL})$ was added to the mixture and the resulting solution was washed with water $(30 \mathrm{~mL}), 2 N$ sodium hydroxide $(3 \times 60 \mathrm{~mL})$, and water $(2 \times 40 \mathrm{~mL})$. The organic layer was dried over anhydrous $\mathrm{MgSO}_{4}$. After filtration and evaporation of the solvent, the product was isolated by column chromatography on silica gel $(20 \%$ ethyl acetate in hexane) and further purified by recrystallization from ethanol to give compound $\mathbf{4 b}$ in $41 \%$ yield. ${ }^{1} \mathrm{H}$ NMR (DMSO-d 6, ppm): $\delta=8.07,7.63,7.32,7.12$ (ddd, aromatic protons, $8 \mathrm{H}$ ), 6.33, 6.22, 5.96 (m, vinyl protons, $3 \mathrm{H}$ ), 4.14 (m, $\left.-\mathrm{OCH}_{2}, 4 \mathrm{H}\right), 2.46\left(\mathrm{t}, \mathrm{CCH}_{2}, 2 \mathrm{H}\right), 1.62-1.22(\mathrm{~m}$, alkyl chain protons, $16 \mathrm{H}), 0.89\left(\mathrm{t},-\mathrm{CH}_{3}, 3 \mathrm{H}\right) . \mathrm{R}\left(\mathrm{KBr}, \mathrm{cm}^{-1}\right)$ : $2935,2860,2244,2145,1739,1719,1636,1608,1408,989$, $879,844,814 .{ }^{13} \mathrm{C}$ NMR $\left(\mathrm{CDCl}_{3}, \mathrm{ppm}\right): \delta=166.5,164.7$, $163.8,151.6,134.0,133.8,132.6,132.5,130.2,128.5$, $122.3,122.1,121.5,119.8,114.6,114.5,85.2,74.7,74.2$, $68.3,65.2,64.7,31.5,29.8,29.2,28.8,28.6,28.4,25.9,22.7$, 19.5, 13.8. Anal. Calcd for $\mathrm{C}_{32} \mathrm{H}_{36} \mathrm{O}_{5}: \mathrm{C}, 76.77 ; \mathrm{H}, 7.25$. Found: C, 76.75; H, 7.32.

For 4a: Yield, 53\%. 'H NMR (DMSO- $d_{6,}$, ppm): $\delta=8.07$, $7.64,7.33,7.12$ (dddd, aromatic protons, $8 \mathrm{H}$ ), 6.32, 6.20, $5.88(\mathrm{~m}$, vinyl protons, $3 \mathrm{H}), 4.11\left(\mathrm{~m},-\mathrm{OCH}_{2}, 4 \mathrm{H}\right), 2.43(\mathrm{t}$, $\mathrm{CCH}_{2}, 2 \mathrm{H}$ ), $1.51-1.38$ (m, alkyl chain protons, $\left.12 \mathrm{H}\right), 0.92$ (t, $\left.-\mathrm{CH}_{3}, 3 \mathrm{H}\right)$. IR $\left(\mathrm{KBr}, \mathrm{cm}^{-1}\right): 2958,2865,2242,2148,1744$, $1713,1636,1600,1409,1006,987,875,851,814,805 .{ }^{13} \mathrm{C}$ NMR $\left(\mathrm{CDCl}_{3}, \mathrm{ppm}\right): \delta=166.5,164.7,163.8,151.6,134.0$, $133.8,132.6,132.5,130.2,128.5,122.4,122.3,121.7$, $120.0,114.9,114.6,85.2,74.7,74.2,68.3,65.3,64.7,30.5$, $29.8,29.2,28.8,25.9,22.2,19.5,13.8$. Anal. Calcd for
$\mathrm{C}_{30} \mathrm{H}_{32} \mathrm{O}_{5}: \mathrm{C}, 76.25 ; \mathrm{H}, 6.83$. Found: $\mathrm{C}, 75.94 ; \mathrm{H}, 6.82$.

For $4 \mathrm{c}$ : Yield, $48 \% .{ }^{1} \mathrm{H}$ NMR (DMSO- $d_{6,}$, ppm): $\delta=7.96$, $7.53,7.22,7.02$ (dddd, aromatic protons, $8 \mathrm{H}$ ), 6.19, 6.11, $5.85(\mathrm{~m}$, vinyl protons, $3 \mathrm{H}), 4.03\left(\mathrm{~m},-\mathrm{OCH}_{2}, 4 \mathrm{H}\right), 2.34(\mathrm{t}$, $\mathrm{CCH}_{2}, 2 \mathrm{H}$ ), 1.64-1.15 (m, alkyl chain protons, $20 \mathrm{H}$ ), 0.76 (t, $\left.-\mathrm{CH}_{3}, 3 \mathrm{H}\right) . \mathrm{IR}\left(\mathrm{KBr}, \mathrm{cm}^{-1}\right): 2931,2854,2243,2145,1737$, $1723,1635,1606,1408,1000,985,875,844,811 .{ }^{13} \mathrm{C} \mathrm{NMR}$ $\left(\mathrm{CDCl}_{3}, \mathrm{ppm}\right): \delta=166.5,164.7,163.8,151.6,134.0,133.8$, $132.6,132.5,130.2,128.5,122.4,122.1,121.4,119.8,114.8$, $114.6,85.2,74.7,74.2,68.3,65.2,64.7,32.1,29.7,29.4$, $29.3,29.2,29.1,28.8,28.5,25.9,22.9,19.8,14.3$. Anal. Calcd for $\mathrm{C}_{34} \mathrm{H}_{40} \mathrm{O}: \mathrm{C}, 77.24 ; \mathrm{H}, 7.63$. Found: $\mathrm{C}, 77.25 ; \mathrm{H}$, 7.66.

For 4 d. Yield, $47 \% .{ }^{1} \mathrm{H}$ NMR (DMSO- $d_{5,}$ ppm): $\delta=8.07$, $7.64,7.32,7.12$ (dddd, aromatic protons, $8 \mathrm{H}$ ), 6.30, 6.21, $5.95(\mathrm{~m}$, vinyl protons, $3 \mathrm{H}), 4.13\left(\mathrm{~m},-\mathrm{OCH}_{2}, 4 \mathrm{H}\right), 2.44(\mathrm{t}$, $\mathrm{CCH}_{2}, 2 \mathrm{H}$ ), 1.75-1.33 (m, alkyl chain protons, $24 \mathrm{H}$ ), 0.88 (t, $\left.-\mathrm{CH}_{3}, 3 \mathrm{H}\right)$. IR $\left(\mathrm{KBr}, \mathrm{cm}^{-1}\right): 2924,2854,2244,2144,1742$, $1721,1634,1602,1409,1006,990,875,853,813,802 .{ }^{13} \mathrm{C}$ NMR ( $\left.\mathrm{CDCl}_{3}, \mathrm{ppm}\right): \delta=166.5,164.7,163.8,151.6,134.0$, $133.8,132.6,132.5,130.2,128.5,122.3,122.1,121.4$, $119.8,114.6,114.5,85.2,74.7,74.2,68.3,65.2,64.7,32.1$, $29.8,29.7,29.6,29.5,29.3,29.2,29.1,28.8,28.5,25.9,22.9$, 19.8, 14.3. Anal. Caled for $\mathrm{C}_{36} \mathrm{H}_{44} \mathrm{O}_{5}: \mathrm{C}, 77.66 ; \mathrm{H}, 7.97$. Found: C, $77.77 ; \mathrm{H}, 8.00$.

Radical Polymerization of Compound $4 \mathrm{~b}$. In a $10 \mathrm{~mL}$ polymerization tube, compound $4 \mathrm{~b}(0.3 \mathrm{~g}, 0.56 \mathrm{mmol})$ and AIBN $(0.0046 \mathrm{~g}, 0.028 \mathrm{mmol})$ were dissolved in dry THF (3 $\mathrm{ml}$ ). The reaction mixture was degassed by a freeze-thaw method to remove oxygen. After sealing the ample, the mixture was heated with stirring at $60^{\circ} \mathrm{C}$ for $48 \mathrm{~h}$. The polymer was isolated and dropped into $n$-hexane to precipitate the polymer. The polymer was dried for $24 \mathrm{~h}$ in vacuum oven. Yield, $36.7 \%$. ${ }^{1} \mathrm{H} \mathrm{NMR}\left(\mathrm{CDCl}_{3}, 300 \mathrm{MHz}\right): \delta$ $=8.15-6.9(8 \mathrm{H}, \mathrm{Ar}-\mathrm{H}), 4.22-2.35\left(6 \mathrm{H},-\mathrm{OCH}_{2}, \mathrm{CCH}_{2}\right), 1.82-$ $1.25(\mathrm{~m}, 19 \mathrm{H}$, polymer backbone and alkyl chain protons), $0.83\left(3 \mathrm{H},-\mathrm{CH}_{3}\right)$.

\section{Results and Discussion}

Synthesis of Polymerizable Mesogens. The rod-like mesogenic monomers were prepared according to Scheme 1. 4-Hydroxybenzoic acid was reacted with 6-chlorohexanol to yield compound 1. An acryl group was introduced to compound 1 by esterification reaction with acrylic acid. The carboxyl end group of acryl compound 2 was converted to acid chloride with thionyl chloride and then reacted with 4-hydroxyphenyldiacetylenes 3 , which were synthesized by the coupling reaction of 1-bromoalkynes with 4-ethynylphenol, to give compounds 4a-d. The structures of all products were identified by ${ }^{1} \mathrm{H}$ and ${ }^{13} \mathrm{C}$ NMR spectroscopy, IR spectroscopy, and elemental analysis.

Mesomorphic Properties. The mesomorphic properties of compounds 4a-d were investigated by DSC, polarized optical microscopy (POM) and X-ray diffractometry. The compounds showed enantiotropic transitions. In the DSC study, sharp phase transitions were observed upon heating 
<smiles>O=C(O)c1ccc(O)cc1</smiles>

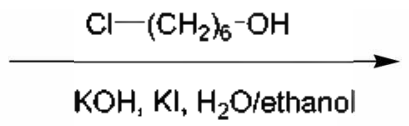<smiles>O=C(O)c1ccc(OCCOO)cc1</smiles><smiles>C=CC(=O)O</smiles>

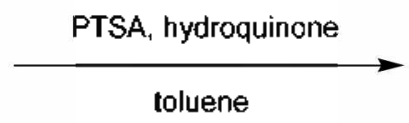<smiles>C=CC(=O)OCCOc1ccc(C(=O)O)cc1</smiles>

2<smiles>CCCC#C[C+]#Cc1ccc(O)cc1</smiles><smiles>CNCCC#CC#Cc1ccc(O)cc1</smiles>

3<smiles>C=CC(=O)OCCOc1ccc(C(=O)Cl)cc1</smiles>

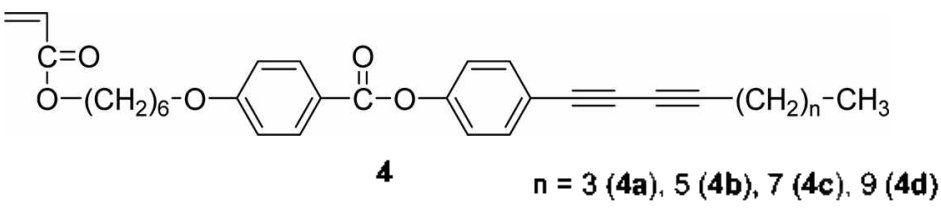

Scheme 1

and cooling with a scan rate of $5^{\circ} \mathrm{C} / \mathrm{min}$. For example, compound $4 \mathrm{~b}$ showed three endothermic peaks at $55.4^{\circ} \mathrm{C}$ $(\Delta H=31.5 \mathrm{~kJ} / \mathrm{mol}), 79.7^{\circ} \mathrm{C}(\Delta H=1.67 \mathrm{~kJ} / \mathrm{mol})$, and $86.1^{\circ} \mathrm{C}$ ( $\Delta H=0.38 \mathrm{~kJ} / \mathrm{mol}$ ) during the $2^{\text {nd }}$ heating, and three exothermic peaks at $84.8{ }^{\circ} \mathrm{C}(\Delta H=0.76 \mathrm{~kJ} / \mathrm{mol}), 78.4{ }^{\circ} \mathrm{C}$ $(\Delta H=1.66 \mathrm{~kJ} / \mathrm{mol})$, and $3.7^{\circ} \mathrm{C}(\Delta H=20.6 \mathrm{~kJ} / \mathrm{mol})$ during

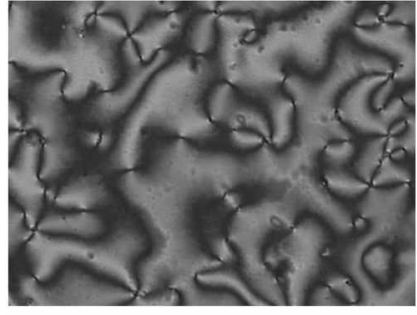

(a)

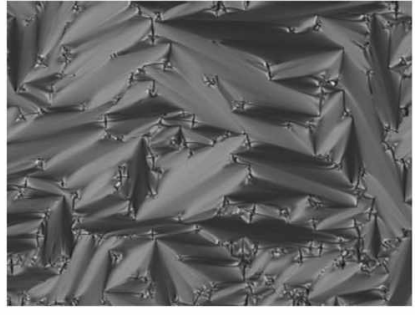

(b)
Figure 1. Polarizing optical micrographs of $4 \mathrm{~b}$ taken (a) at $83^{\circ} \mathrm{C}$ and (b) at $50^{\circ} \mathrm{C}$ on cooling. the $2^{\text {nd }}$ cooling. In POM analysis, a focal conic fan-type texture appeared from $55.4^{\circ} \mathrm{C}$ and then a Schlieren texture above $79.7^{\circ} \mathrm{C}$ on heating, corresponding to a smectic and a nematic phase, respectively (Figure 1). The same textures were observed on cooling. Compounds $4 a$ and $4 \mathbf{c}$ also exhibited two LC phases, but compound $4 \mathbf{d}$ having a longest alkyl tail among the series formed only a smectic phase. The thermal transitions of $\mathbf{4 a -} \mathbf{d}$ are summarized in Table 1.

The structures of the smectic phases of $\mathbf{4 a - 4 d}$ were further investigated by using an $\mathrm{X}$-ray diffraction technique. Figure 2 shows the X-ray diffractogram of $4 \mathrm{~b}$ measured at $50^{\circ} \mathrm{C}$. In the small-angle region, three sharp peaks with $d$ spacings of $35.9,17.8$, and $11.8 \AA$ appeared, corresponding to the (100), $(200)$, and $(300)$ Bragg reflections, respectively. Since the length of the molecule was calculated to be $35.7 \AA$, which was almost the same as the (100) spacing of $35.9 \AA$, it seems that the compound had a monolayered smectic A structure. Other compounds also showed similar results. The X-ray

Table 1. Phase transition temperatures $\left({ }^{\circ} \mathrm{C}\right.$ ) and enthalpy values (in parentheses, $\mathrm{kJ} / \mathrm{mol}$ ) of compounds $4 \mathrm{a}-\mathrm{d}$ determined by DSC at a rate of $5^{\circ} \mathrm{C} \mathrm{min}{ }^{-1}$

\begin{tabular}{ccc}
\hline Compound & $2^{\text {nd }}$ heating & $2^{\text {nd }}$ cooling \\
\hline $\mathbf{4 a}$ & $\mathrm{K} 63.8(33.1) \mathrm{Sm} 83.8(4.36) \mathrm{N} 92.1(0.77) \mathrm{J}$ & $\mathrm{I} 91.7(0.60) \mathrm{N} 83.3(2.16) \mathrm{Sm} 27.2(19.5) \mathrm{K}$ \\
$\mathbf{4 b}$ & $\mathrm{K} 55.4(31.5) \mathrm{Sm} 79.7(1.67) \mathrm{N} 86.1(0.38) \mathrm{J}$ & $\mathrm{J} 84.8(0.76) \mathrm{N} 78.4(1.66) \mathrm{Sm} 3.7(20.6) \mathrm{K}$ \\
$\mathbf{4} \mathbf{c}$ & $\mathrm{K} 21.2(0.8) \mathrm{Sm} 81.5(3.37) \mathrm{N} 84.8(0.95) \mathrm{I}$ & $\mathrm{I} 83.0(0.89) \mathrm{N} 80.0(1.86) \mathrm{Sm}-11.5(0.6) \mathrm{K}$ \\
$\mathbf{4 d}$ & $\mathrm{K} 47.7(26.3) \mathrm{Sm} 82.4(8.27) \mathrm{I}$ & $\mathrm{I} 80.3(7.90) \mathrm{Sm}-6.6(20.4) \mathrm{K}$ \\
\hline
\end{tabular}

${ }^{a} \mathrm{~K}=$ crystal; $\mathrm{Sm}=$ smectic; $\mathrm{N}=$ nemalic; $\mathrm{I}=$ isotropic. 


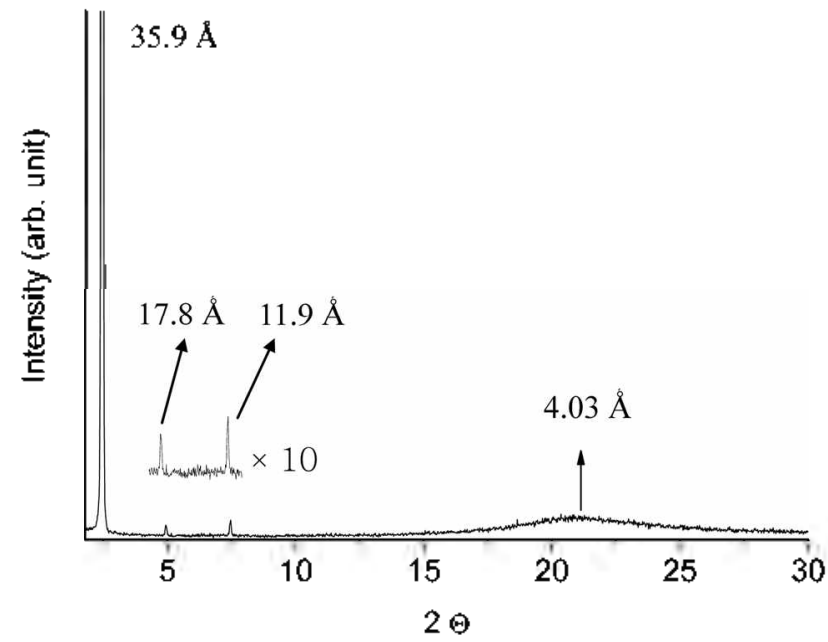

Figure 2. X-ray diffractogram of compound $\mathbf{4 b}$, obtained at $50^{\circ} \mathrm{C}$.

Table 2. X-ray diffraction data of the smectic phases of compounds 4a-d obtained at $50^{\circ} \mathrm{C}$

\begin{tabular}{|c|c|c|c|}
\hline Compound & $d_{c x^{\prime} j^{\prime}}(\AA)^{\prime \prime}$ & $d_{c u t c}(\mathrm{~A})^{\prime}$ & $(h k l)$ \\
\hline \multirow[t]{3}{*}{$4 a$} & 33.2 & 33.5 & $(100)$ \\
\hline & 16.5 & 16.7 & $(200)$ \\
\hline & 10.9 & 11.1 & $(300)$ \\
\hline \multirow[t]{3}{*}{$4 b$} & 35.9 & 35.7 & $(100)$ \\
\hline & 17.8 & 17.8 & $(200)$ \\
\hline & 11.8 & 11.9 & $(300)$ \\
\hline \multirow[t]{3}{*}{$4 c$} & 38.7 & 38.3 & $(100)$ \\
\hline & 18.8 & 19.1 & $(200)$ \\
\hline & 12.6 & 12.7 & $(300)$ \\
\hline \multirow[t]{3}{*}{$4 d$} & 40.9 & 40.9 & $(100)$ \\
\hline & 21.5 & 20.5 & $(200)$ \\
\hline & 14.2 & 13.7 & $(300)$ \\
\hline
\end{tabular}

"Observed from XRD analysis. "Estimated from an extended molecular model.

diffraction data are summarized in Table 2 .

Photopolymerization. Photopolymerizability of an acryl and a diacetylene groups was investigated by IR spectroscopy. A solution of $4 \mathrm{~b}(0.1 \mathrm{~g})$ and a photoinitiator $(2,2-$ dimethoxy-2-phenylacetophenone, $4 \mathrm{wt} \%)$ in toluene $(0.4$ $\mathrm{mL}$ ) was cast on a $\mathrm{KBr}$ window, dried in vacuo, and sheared with a cover glass at $50^{\circ} \mathrm{C}$. The sample was first irradiated with $365 \mathrm{~nm}$ UV light $\left(1 \mathrm{~mW} / \mathrm{cm}^{2}\right)$. The IR band intensity at $1636 \mathrm{~cm}^{-1}$ for $\mathrm{C}=\mathrm{C}$ stretching of a vinyl group gradually decreased with increasing irradiation time, while the intensity of the band at $2241 \mathrm{~cm}^{-1}$ for a diacetylene group changed little, indicating the selective polymerization of the vinyl group (Figure 3). When irradiated with $254 \mathrm{~nm} \mathrm{UV}$ light $\left(3 \mathrm{~mW} / \mathrm{cm}^{2}\right)$, the diacetylene group was polymerized, resulting in a decrease in the intensity of the band at 2241 $\mathrm{cm}^{-1}$. Figure 4 shows a polar plot of the absorbance of the IR peak at $1731 \mathrm{~cm}^{-1}$ versus polarization angle. After shearing in the LC state, the molecules were oriented mostly parallel to the shearing direction. The oriented LC structure was maintained when about $50 \%$ of vinyl groups were polymerized by irradiation with $365 \mathrm{~nm}$ UV light. The
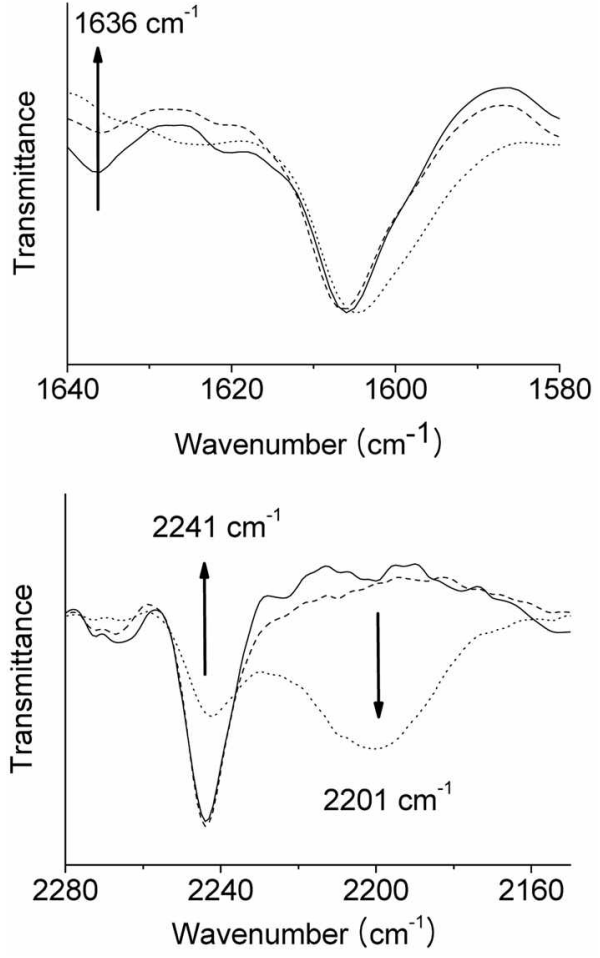

Figure 3. FT-IR spectral changes of compound $\mathbf{4 b}$ : before UV irradiation (solid line), after $365 \mathrm{~nm}$ UV irradiation for $10 \mathrm{~min}$ (dashed line), and after 365 nin UV irradiation for 10 min and 254 nur UV irradiation for 60 unin (dotted line).

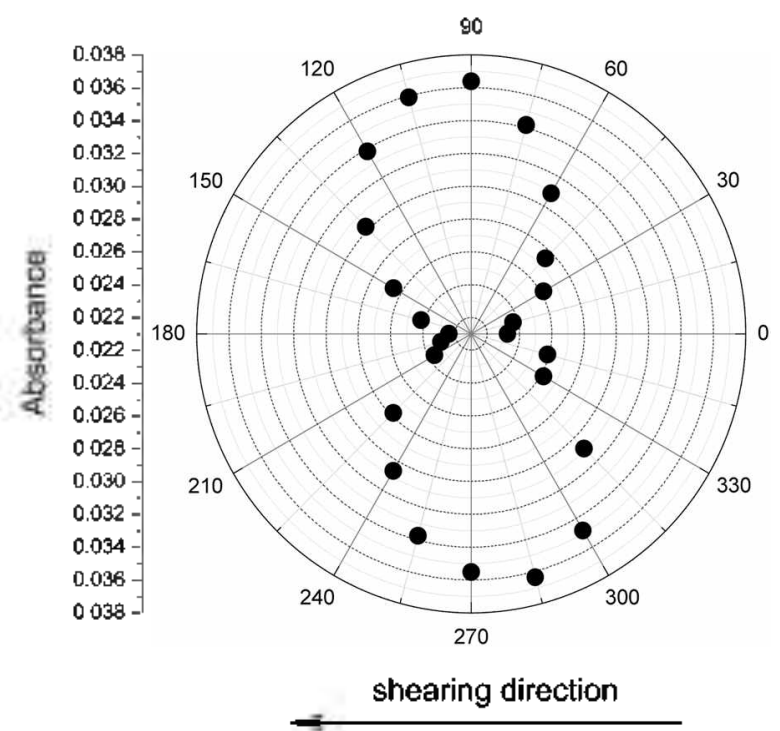

Figure 4. Polar plot of the absorbance of the $I R$ peak for the $C=O$ stretch at $1731 \mathrm{~cm}^{-1}$ versus polarization angle for $4 \mathbf{b}$.

aligned structure was disrupted by irradiation with $254 \mathrm{~nm}$ UV light, which caused cross-linking.

Radical Polymerization. The acryl group of compound 4b could be radically polymerized by initiation with AIBN in THF at $60^{\circ} \mathrm{C}$. Number average molecular weight and weight average molecular weight of the polymer measured by GPC were 7000 and 9790 , respectively. The polymer formed a smectic phase. In DSC analysis, an endothermic 
peak corresponding to isotropization was observed at 96.0 ${ }^{\circ} \mathrm{C}$ on $2^{\text {nd }}$ heating. On cooling, a weak exothermic peak appeared at $92.0^{\circ} \mathrm{C}$. A birefringent phase began to form at $92.0^{\circ} \mathrm{C}$ and persisted to room temperature. In the X-ray diffractogram, a relatively sharp peak with $d$ spacing of 35.2 $\AA$ appeared. We examined the miscibility of $4 \mathrm{~b}$ and the acryl polymer by POM. The $7: 3$ mixture of $4 \mathrm{~b}$ and the polymer showed isotropization at $94^{\circ} \mathrm{C}$. On cooling from the isotropic state with a rate of $5^{\circ} \mathrm{C} / \mathrm{min}$, however, phase separation occurred. This result is in contrast to the observation that the $\mathrm{LC}$ structure was maintained during in-situ polymerization of the vinyl group with $365 \mathrm{~nm}$ UV light in the LC state.

In summary, we prepared LC molecules having two different photopolymerizable groups, i.e. an acryl and a diacetylene group and examined their photoreactivity. An anisotropic polymer film could be prepared by selective polymerization of the acryl group with $365 \mathrm{~nm}$ UV light in the presence of a photoinitiator. The subsequent reaction of diacetylene groups with $254 \mathrm{~nm}$ UV light disrupted the anisotropic structure, suggesting that these LC molecules could be used for imaging on the film.

Acknowledgement. Financial support from the Korea Science and Engineering Foundation, through the Hyperstructured Organic Materials Center is gratefully acknowledged.

\section{References}

I. Broer, D. J.; Mol, G. N. Makronol. Chem. 1989, J90, 19.

2. Ichimura, K. Chem. Rev. 2000, 100, 1847.

3. Yoshio, M.; Kagata, T.; Hoshino, K.; Mukai, T.; Ohno, H.; Kato, T. J. Am. Chem. Soc, 2006, $128,5570$.

4. Penterman, R.; Klink, S. J.; de Koning, H.; Nisato, G.; Broer, D. J. Nafure 2002, 417,55,

5. Kondo, M.; Yu, Y.; Ikeda, T. Angew: Chem., Int. Ed. 2006, 45, 1378.

6. Ree, M. Macronol. Res. 2006, 14, 1 .

7. Baxter, B. C.; Gin, D. L. Macromolecules 1998, 3I, 4419.

8. Hoag, B. P.; Gin, D. L. Macromolecules $2000,33,8549$.

9. Vlachos, P; Kelly, S. M.; Mansoor, B.; ÓNeill, M. Chem. Commun 2002, 874.

10. Beyer, P.; Krueger, M.; Giesselmann, F.; Zentel, R. Adv: Funct. Mater. 2007, 17, 109 .

11. Chang, J. Y.; Nam, S. W.; Hong, C. G.; Im, J.-H.; Kim, J.-H.; Han, M. J. Adv. Mater, 2001, 13, 1298 .

12. Nam, S. W,; Kang, S. H.; Chang, J. Y. Macromol. Res. 2007, 15, 74.

13. Cho, H. J.; Seo, K.; Lee, C. J.; Yun, H.; Chang, J. Y. J. Mater. Chem. 2003, 13,986.

14. Lee, C. J.; Lee, S. J.; Chang, J. Y. Tetrahedron Lett. 2002, 43, 3863 .

15. Hwang, I. H.; Lee, S. J.; Chang, J. Y. J. Polym. Sci, Polym. Chem. Ed. 2003, 41, 1881 .

16. Chang. J. Y;; Baik, J. H.; Lee, C. B.; Han, M. J.; Hong, S.-K. J. An. Chent. Soc. 1997, 119, 3197.

17. Chang. J. Y.; Yeon, J. R.; Shin, Y. S.; Han, M. J.; Hong, S.-K. Chem. Mater, 2000, 12, 1076. 


\title{
Synthesis and Characterization of Photopolymerizable Liquid Crystalline Compounds Having Two Reactive Sites
}

\author{
Ki Suk Jang, Suk Hoon Kang, and Ji Young Chang* \\ Department of Materials Science and Engineering, and Hyperstnctured Organic Materials Research Center, \\ College of Engineering, Seonl National University, Seonl 151-744, Korea. "E-mail:jichang@smiac.kr \\ Received June 18, 2007
}

\begin{abstract}
Rod-like polymerizable LC molecules having two different reactive groups, i.e acryl and diacetylene groups were prepared. 4-IIydroxyphenyldiacetylenes were synthesized by the coupling reaction of 1-bromoalkynes with 4-ethynylphenol and then reacted with 4-(6-acryloyloxyalkyloxy)benzoic acid to give polymerizable LC molecules 4a-d. The mesomorphic properties of compounds $4 \mathbf{a}-\mathbf{d}$ were investigated by differential scanning calorimetry, polarized optical microscopy and X-ray diffractometry. Compounds 4a-c exhibited smectic and nematic phases, but compound $\mathbf{4 d}$ having a longest alkyl tail among the series formed only a smectic phase. Photopolymerizability of acryl and diacetylene groups was investigated by $\mathbb{R}$ spectroscopy. An anisotropic polymer film could be prepared by selective polymerization of acryl groups with $365 \mathrm{~nm}$ UV light in the presence of a photoinitiator (2,2-dimethoxy-2-phenylacetophenone). The subsequent reaction of diacetylene groups with $254 \mathrm{~nm}$ UV light disrupted the anisotropic structure, suggesting that these LC molecules could be used for imaging on the film.
\end{abstract}

Key Words : Polymerizable liquid crystal, Diacetylene, UV irradiation, Photopolymerization

\section{Introduction}

Photopolymerizable liquid crystal (LC) monomers are of great interest because of their potential applications in display and data storage industries. ${ }^{1-3}$ They can be macroscopically oriented under electric or magnetic fields, and on mechanically rubbed substrates. Their in-situ photopolymerization in the LC state produces an anisotropic film having an aligned structure of LC molecules. ${ }^{4-10}$

There are two general methods for preparing an LC monomer. Firstly vinyl groups can be attached to both sides of a mesogen through flexible spacers. In the second method, photoreactive groups are introduced into mesogens to become parts of rigid rods. We previously reported LC molecules having two chalcone units ${ }^{11.12}$ or two diacetylene groups $^{13}$ as parts of rigid rods. A chalcone is known to form a dimer by $[2+2]$ addition reaction when exposed to UV light. The polymerization of the LC molecules having two chalcone units proceeds in a stepwise manner. The polymerization of diacetylenes occurs topochemically via 1,4addition by irradiation ${ }^{1+17}$ Since theses molecules had two reactive sites within one structure, the photopolymerization in the LC state distupted an aligned structure, resulting in optical property changes. When the photopolymerization was carried out through a photomask, an excellent-patterned image was obtained.

In this work, we prepared rod-like LC molecules having two different photopolymerizable groups, i.e. acryl and diacetylene groups. We introduced an acryl group at one end of a mesogen through a flexible spacer and a phenyl diacetylene group as a part of rigid rod. Since two functional groups have different photoreactivity, we expected the selective reaction of each group, depending on irradiation conditions. We report here the synthesis and polymerization of heterobifunctional LC molecules.

\section{Experimental Section}

Measurements. ${ }^{1} \mathrm{H}$ and ${ }^{13} \mathrm{C}$ NMR spectra were recorded on a BRUKER Avance DPX-300 and Avance 500 spectrometer. FT-IR spectra were obtained with PERKIN ELMER Spectrum GX I using a $\mathrm{KBr}$ window. The differential scanning calorimetry (DSC) measurements were performed with a TA modulated DSC 2090. X-ray diffractograms were obtained by using a Mac Science M18XHF-SRA (Cu K radiation, $\lambda=1.54 \AA$ ). The optical microscopy study was performed using a Leica DM LP equipped with Mettler Toledo FP 82HT heating stage and Mettler Toledo FP 90 central process controllex. Elemental analysis was performed using a CE instrument EA 1110 analyzer.

Synthesis of 4-(6-Hydroxyhexyloxy)benzoic acid (1). 4Hydroxybenzoic acid ( $10 \mathrm{~g}, 72.40 \mathrm{mmol})$ was dissolved in a mixture of ethanol $(30 \mathrm{~mL})$ and water $(20 \mathrm{~mL})$ along with potassium hydroxide $(10.78 \mathrm{~g}, 192 \mathrm{mmol})$ and a pinch of potassium iodide. 1-Chloro-6-hydroxyhexane $(9.01 \mathrm{~g}, 66$ $\mathrm{mmol}$ ) was added slowly to the mixture at room temperature while stirring vigorously, and then the mixture was refluxed for $48 \mathrm{~h}$. After evaporation of the solvents, the solid residue was dissolved in water $(120 \mathrm{~mL})$ and washed with diethyl ether $(3 \times 30 \mathrm{~mL})$. The aqueous layer was acidified with concentrated $\mathrm{HCl}$ until the $\mathrm{pH}$ was 2 . The precipitates were isolated by filtration, washed with water, and recrystallized from ethanol to give compound 1 in $54 \%$ yield. ${ }^{1} \mathrm{H}$ NMR $\left(\mathrm{CDCl}_{3}, \mathrm{ppm}\right): \delta=8.08,6.95$ (dd, aromatic protons, $4 \mathrm{H}$ ), $4.20(\mathrm{~s},-\mathrm{OH}, 1 \mathrm{H}), 4.05\left(\mathrm{t},-\mathrm{OCH}_{2}, 2 \mathrm{H}\right), 1.87-1.48(\mathrm{~m}$, alkyl chain protons, $8 \mathrm{H}$ ). 
Synthesis of 4-(6-Acryloyloxyhexyloxy)benzoic Acid (2). Compound $1(5 \mathrm{~g}, 21.53 \mathrm{mmol})$, acrylic acid $(5.71 \mathrm{~mL}$, $83.3 \mathrm{mmol}), p$-toluene sulfonic acid $(1.40 \mathrm{~g}, 7.35 \mathrm{mmol})$, and hydroquinone $(0.47 \mathrm{~g}, 4.27 \mathrm{mmol})$ were dissolved in toluene. The solution was refluxed for $12 \mathrm{~h}$ in a flask equipped with a Dean-stark trap. After evaporation of the solvent, the residue was dissolved in chloroform $(40 \mathrm{~mL})$, diluted with diethyl ether $(200 \mathrm{~mL})$, and washed with warm water until no more acrylic acid was detected. The organic layer was dried over anhydrous $\mathrm{MgSO}_{4}$. After filtration and evaporation of the solvent, the solid residue was recrystallized from isopropanol to give compound 2 in $48 \%$ yield. ' $\mathrm{H}$ NMR $\left(\mathrm{CDCl}_{3}, \mathrm{ppm}\right): \delta=8.08,6.95$ (dd, aromatic protons, $4 \mathrm{H}), 6.45,6.19,5.86(\mathrm{~m}$, vinyl protons, $3 \mathrm{H}), 4.22,4.07$ (t, $-\mathrm{OCH}_{2}, 4 \mathrm{H}$ ), 1.87-1.46 (m, alkyl chain protons, $8 \mathrm{H}$ ).

Synthesis of Compound 3 . Compound 3 was prepared according to our previous report. ${ }^{13}$

Synthesis of Compound 4. A typical procedure is as follows. To compound $2(1.84 \mathrm{~g}, 6.32 \mathrm{mmol})$ were added thionyl chloride $(2.79 \mathrm{~g}, 23.48 \mathrm{mmol}), 2,6$-di-t-butyl 4methylphenol $(0.44 \mathrm{~g}, 1.99 \mathrm{mmol})$ as an inhibitor, and a catalytic amount of dimethylformamide (DMF) (two drops). After stirring for $40 \mathrm{~min}$, the excess thionyl chloride was removed under reduced pressure. The residue was dissolved in chloroform $(8 \mathrm{~mL})$, and to the solution was added dropwise a solution of compound $3(n=5)(1.10 \mathrm{~g}, 4.86$ $\mathrm{mmol})$ and triethylamine $(0.54 \mathrm{~g}, 5.35 \mathrm{mmol})$ in chloroform $(15 \mathrm{~mL})$ at $0^{\circ} \mathrm{C}$. After stirring for $16 \mathrm{~h}$ at room temperature, chloroform $(100 \mathrm{~mL})$ was added to the mixture and the resulting solution was washed with water $(30 \mathrm{~mL}), 2 N$ sodium hydroxide $(3 \times 60 \mathrm{~mL})$, and water $(2 \times 40 \mathrm{~mL})$. The organic layer was dried over anhydrous $\mathrm{MgSO}_{4}$. After filtration and evaporation of the solvent, the product was isolated by column chromatography on silica gel $(20 \%$ ethyl acetate in hexane) and further purified by recrystallization from ethanol to give compound $\mathbf{4 b}$ in $41 \%$ yield. ${ }^{1} \mathrm{H}$ NMR (DMSO-d 6, ppm): $\delta=8.07,7.63,7.32,7.12$ (ddd, aromatic protons, $8 \mathrm{H}$ ), 6.33, 6.22, 5.96 (m, vinyl protons, $3 \mathrm{H}$ ), 4.14 (m, $\left.-\mathrm{OCH}_{2}, 4 \mathrm{H}\right), 2.46\left(\mathrm{t}, \mathrm{CCH}_{2}, 2 \mathrm{H}\right), 1.62-1.22(\mathrm{~m}$, alkyl chain protons, $16 \mathrm{H}), 0.89\left(\mathrm{t},-\mathrm{CH}_{3}, 3 \mathrm{H}\right) . \mathrm{R}\left(\mathrm{KBr}, \mathrm{cm}^{-1}\right)$ : $2935,2860,2244,2145,1739,1719,1636,1608,1408,989$, $879,844,814 .{ }^{13} \mathrm{C}$ NMR $\left(\mathrm{CDCl}_{3}, \mathrm{ppm}\right): \delta=166.5,164.7$, $163.8,151.6,134.0,133.8,132.6,132.5,130.2,128.5$, $122.3,122.1,121.5,119.8,114.6,114.5,85.2,74.7,74.2$, $68.3,65.2,64.7,31.5,29.8,29.2,28.8,28.6,28.4,25.9,22.7$, 19.5, 13.8. Anal. Calcd for $\mathrm{C}_{32} \mathrm{H}_{36} \mathrm{O}_{5}: \mathrm{C}, 76.77 ; \mathrm{H}, 7.25$. Found: C, 76.75; H, 7.32.

For 4a: Yield, 53\%. 'H NMR (DMSO- $d_{6,}$, ppm): $\delta=8.07$, $7.64,7.33,7.12$ (dddd, aromatic protons, $8 \mathrm{H}$ ), 6.32, 6.20, $5.88(\mathrm{~m}$, vinyl protons, $3 \mathrm{H}), 4.11\left(\mathrm{~m},-\mathrm{OCH}_{2}, 4 \mathrm{H}\right), 2.43(\mathrm{t}$, $\mathrm{CCH}_{2}, 2 \mathrm{H}$ ), $1.51-1.38$ (m, alkyl chain protons, $\left.12 \mathrm{H}\right), 0.92$ (t, $\left.-\mathrm{CH}_{3}, 3 \mathrm{H}\right)$. IR $\left(\mathrm{KBr}, \mathrm{cm}^{-1}\right): 2958,2865,2242,2148,1744$, $1713,1636,1600,1409,1006,987,875,851,814,805 .{ }^{13} \mathrm{C}$ NMR $\left(\mathrm{CDCl}_{3}, \mathrm{ppm}\right): \delta=166.5,164.7,163.8,151.6,134.0$, $133.8,132.6,132.5,130.2,128.5,122.4,122.3,121.7$, $120.0,114.9,114.6,85.2,74.7,74.2,68.3,65.3,64.7,30.5$, $29.8,29.2,28.8,25.9,22.2,19.5,13.8$. Anal. Calcd for
$\mathrm{C}_{30} \mathrm{H}_{32} \mathrm{O}_{5}: \mathrm{C}, 76.25 ; \mathrm{H}, 6.83$. Found: $\mathrm{C}, 75.94 ; \mathrm{H}, 6.82$.

For $4 \mathrm{c}$ : Yield, $48 \% .{ }^{1} \mathrm{H}$ NMR (DMSO- $d_{6,}$, ppm): $\delta=7.96$, $7.53,7.22,7.02$ (dddd, aromatic protons, $8 \mathrm{H}$ ), 6.19, 6.11, $5.85(\mathrm{~m}$, vinyl protons, $3 \mathrm{H}), 4.03\left(\mathrm{~m},-\mathrm{OCH}_{2}, 4 \mathrm{H}\right), 2.34(\mathrm{t}$, $\mathrm{CCH}_{2}, 2 \mathrm{H}$ ), 1.64-1.15 (m, alkyl chain protons, $20 \mathrm{H}$ ), 0.76 (t, $\left.-\mathrm{CH}_{3}, 3 \mathrm{H}\right) . \mathrm{IR}\left(\mathrm{KBr}, \mathrm{cm}^{-1}\right): 2931,2854,2243,2145,1737$, $1723,1635,1606,1408,1000,985,875,844,811 .{ }^{13} \mathrm{C} \mathrm{NMR}$ $\left(\mathrm{CDCl}_{3}, \mathrm{ppm}\right): \delta=166.5,164.7,163.8,151.6,134.0,133.8$, $132.6,132.5,130.2,128.5,122.4,122.1,121.4,119.8,114.8$, $114.6,85.2,74.7,74.2,68.3,65.2,64.7,32.1,29.7,29.4$, $29.3,29.2,29.1,28.8,28.5,25.9,22.9,19.8,14.3$. Anal. Calcd for $\mathrm{C}_{34} \mathrm{H}_{40} \mathrm{O}: \mathrm{C}, 77.24 ; \mathrm{H}, 7.63$. Found: $\mathrm{C}, 77.25 ; \mathrm{H}$, 7.66.

For 4 d. Yield, $47 \% .{ }^{1} \mathrm{H}$ NMR (DMSO- $d_{5,}$ ppm): $\delta=8.07$, $7.64,7.32,7.12$ (dddd, aromatic protons, $8 \mathrm{H}$ ), 6.30, 6.21, $5.95(\mathrm{~m}$, vinyl protons, $3 \mathrm{H}), 4.13\left(\mathrm{~m},-\mathrm{OCH}_{2}, 4 \mathrm{H}\right), 2.44(\mathrm{t}$, $\mathrm{CCH}_{2}, 2 \mathrm{H}$ ), 1.75-1.33 (m, alkyl chain protons, $24 \mathrm{H}$ ), 0.88 (t, $\left.-\mathrm{CH}_{3}, 3 \mathrm{H}\right)$. IR $\left(\mathrm{KBr}, \mathrm{cm}^{-1}\right): 2924,2854,2244,2144,1742$, $1721,1634,1602,1409,1006,990,875,853,813,802 .{ }^{13} \mathrm{C}$ NMR ( $\left.\mathrm{CDCl}_{3}, \mathrm{ppm}\right): \delta=166.5,164.7,163.8,151.6,134.0$, $133.8,132.6,132.5,130.2,128.5,122.3,122.1,121.4$, $119.8,114.6,114.5,85.2,74.7,74.2,68.3,65.2,64.7,32.1$, $29.8,29.7,29.6,29.5,29.3,29.2,29.1,28.8,28.5,25.9,22.9$, 19.8, 14.3. Anal. Caled for $\mathrm{C}_{36} \mathrm{H}_{44} \mathrm{O}_{5}: \mathrm{C}, 77.66 ; \mathrm{H}, 7.97$. Found: C, $77.77 ; \mathrm{H}, 8.00$.

Radical Polymerization of Compound $4 \mathrm{~b}$. In a $10 \mathrm{~mL}$ polymerization tube, compound $4 \mathrm{~b}(0.3 \mathrm{~g}, 0.56 \mathrm{mmol})$ and AIBN $(0.0046 \mathrm{~g}, 0.028 \mathrm{mmol})$ were dissolved in dry THF (3 $\mathrm{ml}$ ). The reaction mixture was degassed by a freeze-thaw method to remove oxygen. After sealing the ample, the mixture was heated with stirring at $60^{\circ} \mathrm{C}$ for $48 \mathrm{~h}$. The polymer was isolated and dropped into $n$-hexane to precipitate the polymer. The polymer was dried for $24 \mathrm{~h}$ in vacuum oven. Yield, $36.7 \%$. ${ }^{1} \mathrm{H} \mathrm{NMR}\left(\mathrm{CDCl}_{3}, 300 \mathrm{MHz}\right): \delta$ $=8.15-6.9(8 \mathrm{H}, \mathrm{Ar}-\mathrm{H}), 4.22-2.35\left(6 \mathrm{H},-\mathrm{OCH}_{2}, \mathrm{CCH}_{2}\right), 1.82-$ $1.25(\mathrm{~m}, 19 \mathrm{H}$, polymer backbone and alkyl chain protons), $0.83\left(3 \mathrm{H},-\mathrm{CH}_{3}\right)$.

\section{Results and Discussion}

Synthesis of Polymerizable Mesogens. The rod-like mesogenic monomers were prepared according to Scheme 1. 4-Hydroxybenzoic acid was reacted with 6-chlorohexanol to yield compound 1. An acryl group was introduced to compound 1 by esterification reaction with acrylic acid. The carboxyl end group of acryl compound 2 was converted to acid chloride with thionyl chloride and then reacted with 4-hydroxyphenyldiacetylenes 3 , which were synthesized by the coupling reaction of 1-bromoalkynes with 4-ethynylphenol, to give compounds 4a-d. The structures of all products were identified by ${ }^{1} \mathrm{H}$ and ${ }^{13} \mathrm{C}$ NMR spectroscopy, IR spectroscopy, and elemental analysis.

Mesomorphic Properties. The mesomorphic properties of compounds 4a-d were investigated by DSC, polarized optical microscopy (POM) and X-ray diffractometry. The compounds showed enantiotropic transitions. In the DSC study, sharp phase transitions were observed upon heating 
<smiles>O=C(O)c1ccc(O)cc1</smiles>

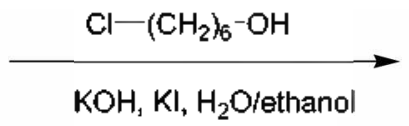<smiles>O=C(O)c1ccc(OCCOO)cc1</smiles><smiles>C=CC(=O)O</smiles>

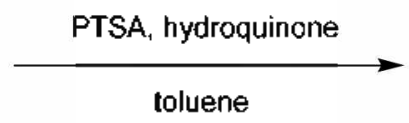<smiles>C=CC(=O)OCCOc1ccc(C(=O)O)cc1</smiles>

2<smiles>CCCC#C[C+]#Cc1ccc(O)cc1</smiles><smiles>CNCCC#CC#Cc1ccc(O)cc1</smiles>

3<smiles>C=CC(=O)OCCOc1ccc(C(=O)Cl)cc1</smiles>

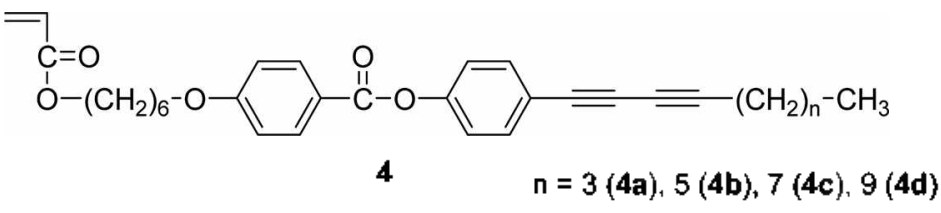

Scheme 1

and cooling with a scan rate of $5^{\circ} \mathrm{C} / \mathrm{min}$. For example, compound $4 \mathrm{~b}$ showed three endothermic peaks at $55.4^{\circ} \mathrm{C}$ $(\Delta H=31.5 \mathrm{~kJ} / \mathrm{mol}), 79.7^{\circ} \mathrm{C}(\Delta H=1.67 \mathrm{~kJ} / \mathrm{mol})$, and $86.1^{\circ} \mathrm{C}$ ( $\Delta H=0.38 \mathrm{~kJ} / \mathrm{mol}$ ) during the $2^{\text {nd }}$ heating, and three exothermic peaks at $84.8{ }^{\circ} \mathrm{C}(\Delta H=0.76 \mathrm{~kJ} / \mathrm{mol}), 78.4{ }^{\circ} \mathrm{C}$ $(\Delta H=1.66 \mathrm{~kJ} / \mathrm{mol})$, and $3.7^{\circ} \mathrm{C}(\Delta H=20.6 \mathrm{~kJ} / \mathrm{mol})$ during

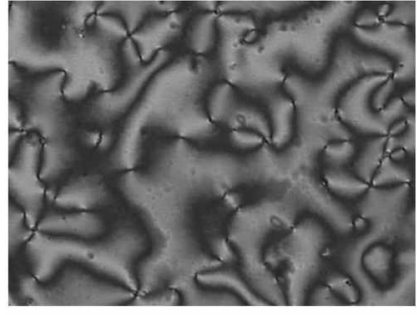

(a)

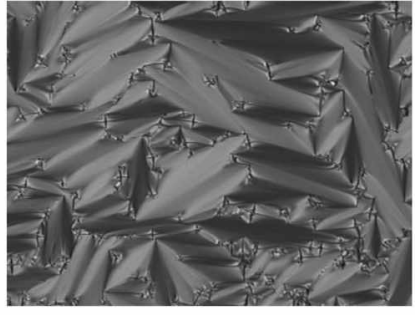

(b)
Figure 1. Polarizing optical micrographs of $4 \mathrm{~b}$ taken (a) at $83^{\circ} \mathrm{C}$ and (b) at $50^{\circ} \mathrm{C}$ on cooling. the $2^{\text {nd }}$ cooling. In POM analysis, a focal conic fan-type texture appeared from $55.4^{\circ} \mathrm{C}$ and then a Schlieren texture above $79.7^{\circ} \mathrm{C}$ on heating, corresponding to a smectic and a nematic phase, respectively (Figure 1). The same textures were observed on cooling. Compounds $4 a$ and $4 \mathbf{c}$ also exhibited two LC phases, but compound $4 \mathbf{d}$ having a longest alkyl tail among the series formed only a smectic phase. The thermal transitions of $\mathbf{4 a -} \mathbf{d}$ are summarized in Table 1.

The structures of the smectic phases of $\mathbf{4 a - 4 d}$ were further investigated by using an $\mathrm{X}$-ray diffraction technique. Figure 2 shows the X-ray diffractogram of $4 \mathrm{~b}$ measured at $50^{\circ} \mathrm{C}$. In the small-angle region, three sharp peaks with $d$ spacings of $35.9,17.8$, and $11.8 \AA$ appeared, corresponding to the (100), $(200)$, and $(300)$ Bragg reflections, respectively. Since the length of the molecule was calculated to be $35.7 \AA$, which was almost the same as the (100) spacing of $35.9 \AA$, it seems that the compound had a monolayered smectic A structure. Other compounds also showed similar results. The X-ray

Table 1. Phase transition temperatures $\left({ }^{\circ} \mathrm{C}\right.$ ) and enthalpy values (in parentheses, $\mathrm{kJ} / \mathrm{mol}$ ) of compounds $4 \mathrm{a}-\mathrm{d}$ determined by DSC at a rate of $5^{\circ} \mathrm{C} \mathrm{min}{ }^{-1}$

\begin{tabular}{ccc}
\hline Compound & $2^{\text {nd }}$ heating & $2^{\text {nd }}$ cooling \\
\hline $\mathbf{4 a}$ & $\mathrm{K} 63.8(33.1) \mathrm{Sm} 83.8(4.36) \mathrm{N} 92.1(0.77) \mathrm{J}$ & $\mathrm{I} 91.7(0.60) \mathrm{N} 83.3(2.16) \mathrm{Sm} 27.2(19.5) \mathrm{K}$ \\
$\mathbf{4 b}$ & $\mathrm{K} 55.4(31.5) \mathrm{Sm} 79.7(1.67) \mathrm{N} 86.1(0.38) \mathrm{J}$ & $\mathrm{J} 84.8(0.76) \mathrm{N} 78.4(1.66) \mathrm{Sm} 3.7(20.6) \mathrm{K}$ \\
$\mathbf{4} \mathbf{c}$ & $\mathrm{K} 21.2(0.8) \mathrm{Sm} 81.5(3.37) \mathrm{N} 84.8(0.95) \mathrm{I}$ & $\mathrm{I} 83.0(0.89) \mathrm{N} 80.0(1.86) \mathrm{Sm}-11.5(0.6) \mathrm{K}$ \\
$\mathbf{4 d}$ & $\mathrm{K} 47.7(26.3) \mathrm{Sm} 82.4(8.27) \mathrm{I}$ & $\mathrm{I} 80.3(7.90) \mathrm{Sm}-6.6(20.4) \mathrm{K}$ \\
\hline
\end{tabular}

${ }^{a} \mathrm{~K}=$ crystal; $\mathrm{Sm}=$ smectic; $\mathrm{N}=$ nemalic; $\mathrm{I}=$ isotropic. 


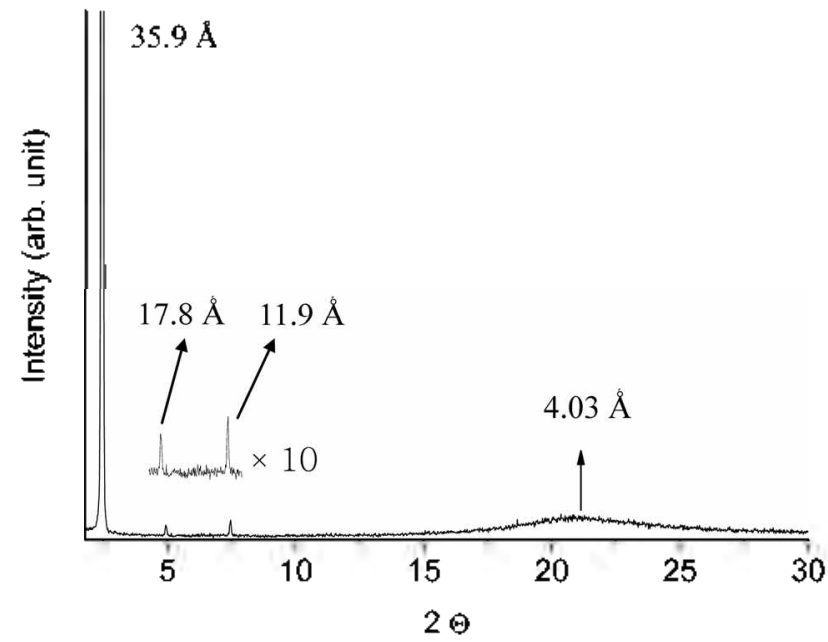

Figure 2. X-ray diffractogram of compound $\mathbf{4 b}$, obtained at $50^{\circ} \mathrm{C}$.

Table 2. X-ray diffraction data of the smectic phases of compounds 4a-d obtained at $50^{\circ} \mathrm{C}$

\begin{tabular}{|c|c|c|c|}
\hline Compound & $d_{c x^{\prime} j^{\prime}}(\AA)^{\prime \prime}$ & $d_{c u t c}(\mathrm{~A})^{\prime}$ & $(h k l)$ \\
\hline \multirow[t]{3}{*}{$4 a$} & 33.2 & 33.5 & $(100)$ \\
\hline & 16.5 & 16.7 & $(200)$ \\
\hline & 10.9 & 11.1 & $(300)$ \\
\hline \multirow[t]{3}{*}{$4 b$} & 35.9 & 35.7 & $(100)$ \\
\hline & 17.8 & 17.8 & $(200)$ \\
\hline & 11.8 & 11.9 & $(300)$ \\
\hline \multirow[t]{3}{*}{$4 c$} & 38.7 & 38.3 & $(100)$ \\
\hline & 18.8 & 19.1 & $(200)$ \\
\hline & 12.6 & 12.7 & $(300)$ \\
\hline \multirow[t]{3}{*}{$4 d$} & 40.9 & 40.9 & $(100)$ \\
\hline & 21.5 & 20.5 & $(200)$ \\
\hline & 14.2 & 13.7 & $(300)$ \\
\hline
\end{tabular}

"Observed from XRD analysis. "Estimated from an extended molecular model.

diffraction data are summarized in Table 2 .

Photopolymerization. Photopolymerizability of an acryl and a diacetylene groups was investigated by IR spectroscopy. A solution of $4 \mathrm{~b}(0.1 \mathrm{~g})$ and a photoinitiator $(2,2-$ dimethoxy-2-phenylacetophenone, $4 \mathrm{wt} \%)$ in toluene $(0.4$ $\mathrm{mL}$ ) was cast on a $\mathrm{KBr}$ window, dried in vacuo, and sheared with a cover glass at $50^{\circ} \mathrm{C}$. The sample was first irradiated with $365 \mathrm{~nm}$ UV light $\left(1 \mathrm{~mW} / \mathrm{cm}^{2}\right)$. The IR band intensity at $1636 \mathrm{~cm}^{-1}$ for $\mathrm{C}=\mathrm{C}$ stretching of a vinyl group gradually decreased with increasing irradiation time, while the intensity of the band at $2241 \mathrm{~cm}^{-1}$ for a diacetylene group changed little, indicating the selective polymerization of the vinyl group (Figure 3). When irradiated with $254 \mathrm{~nm} \mathrm{UV}$ light $\left(3 \mathrm{~mW} / \mathrm{cm}^{2}\right)$, the diacetylene group was polymerized, resulting in a decrease in the intensity of the band at 2241 $\mathrm{cm}^{-1}$. Figure 4 shows a polar plot of the absorbance of the IR peak at $1731 \mathrm{~cm}^{-1}$ versus polarization angle. After shearing in the LC state, the molecules were oriented mostly parallel to the shearing direction. The oriented LC structure was maintained when about $50 \%$ of vinyl groups were polymerized by irradiation with $365 \mathrm{~nm}$ UV light. The
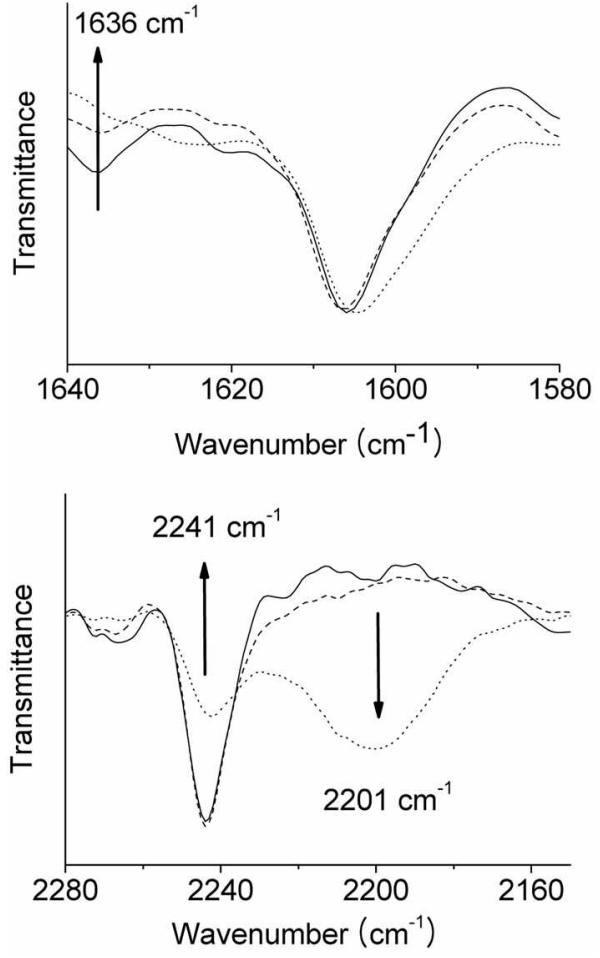

Figure 3. FT-IR spectral changes of compound $\mathbf{4 b}$ : before UV irradiation (solid line), after $365 \mathrm{~nm}$ UV irradiation for $10 \mathrm{~min}$ (dashed line), and after 365 nin UV irradiation for 10 min and 254 nur UV irradiation for 60 unin (dotted line).

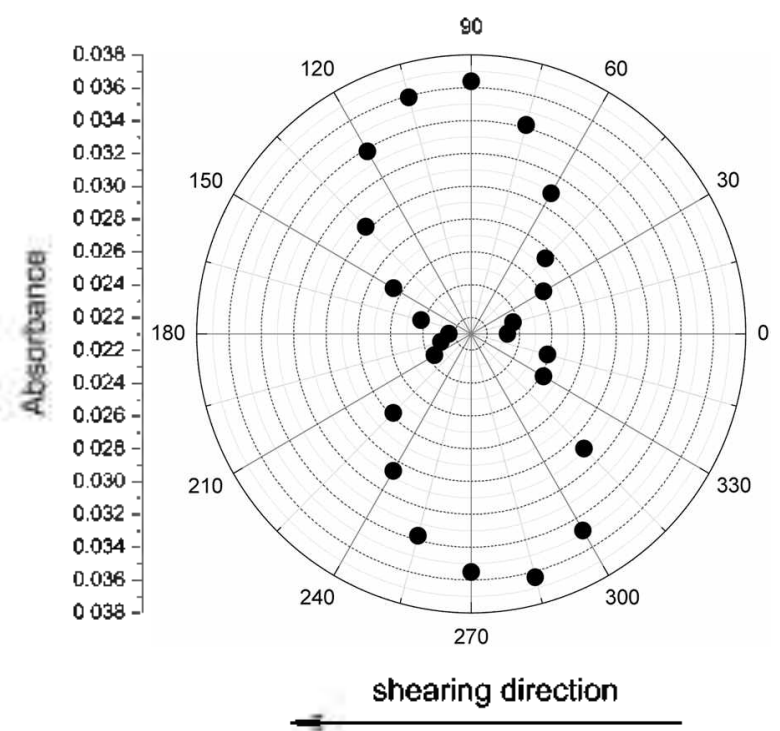

Figure 4. Polar plot of the absorbance of the $I R$ peak for the $C=O$ stretch at $1731 \mathrm{~cm}^{-1}$ versus polarization angle for $4 \mathbf{b}$.

aligned structure was disrupted by irradiation with $254 \mathrm{~nm}$ UV light, which caused cross-linking.

Radical Polymerization. The acryl group of compound 4b could be radically polymerized by initiation with AIBN in THF at $60^{\circ} \mathrm{C}$. Number average molecular weight and weight average molecular weight of the polymer measured by GPC were 7000 and 9790 , respectively. The polymer formed a smectic phase. In DSC analysis, an endothermic 
peak corresponding to isotropization was observed at 96.0 ${ }^{\circ} \mathrm{C}$ on $2^{\text {nd }}$ heating. On cooling, a weak exothermic peak appeared at $92.0^{\circ} \mathrm{C}$. A birefringent phase began to form at $92.0^{\circ} \mathrm{C}$ and persisted to room temperature. In the X-ray diffractogram, a relatively sharp peak with $d$ spacing of 35.2 $\AA$ appeared. We examined the miscibility of $4 \mathrm{~b}$ and the acryl polymer by POM. The $7: 3$ mixture of $4 \mathrm{~b}$ and the polymer showed isotropization at $94^{\circ} \mathrm{C}$. On cooling from the isotropic state with a rate of $5^{\circ} \mathrm{C} / \mathrm{min}$, however, phase separation occurred. This result is in contrast to the observation that the $\mathrm{LC}$ structure was maintained during in-situ polymerization of the vinyl group with $365 \mathrm{~nm}$ UV light in the LC state.

In summary, we prepared LC molecules having two different photopolymerizable groups, i.e. an acryl and a diacetylene group and examined their photoreactivity. An anisotropic polymer film could be prepared by selective polymerization of the acryl group with $365 \mathrm{~nm}$ UV light in the presence of a photoinitiator. The subsequent reaction of diacetylene groups with $254 \mathrm{~nm}$ UV light disrupted the anisotropic structure, suggesting that these LC molecules could be used for imaging on the film.

Acknowledgement. Financial support from the Korea Science and Engineering Foundation, through the Hyperstructured Organic Materials Center is gratefully acknowledged.

\section{References}

I. Broer, D. J.; Mol, G. N. Makronol. Chem. 1989, J90, 19.

2. Ichimura, K. Chem. Rev. 2000, 100, 1847.

3. Yoshio, M.; Kagata, T.; Hoshino, K.; Mukai, T.; Ohno, H.; Kato, T. J. Am. Chem. Soc, 2006, $128,5570$.

4. Penterman, R.; Klink, S. J.; de Koning, H.; Nisato, G.; Broer, D. J. Nafure 2002, 417,55,

5. Kondo, M.; Yu, Y.; Ikeda, T. Angew: Chem., Int. Ed. 2006, 45, 1378.

6. Ree, M. Macronol. Res. 2006, 14, 1 .

7. Baxter, B. C.; Gin, D. L. Macromolecules 1998, 3I, 4419.

8. Hoag, B. P.; Gin, D. L. Macromolecules $2000,33,8549$.

9. Vlachos, P; Kelly, S. M.; Mansoor, B.; ÓNeill, M. Chem. Commun 2002, 874.

10. Beyer, P.; Krueger, M.; Giesselmann, F.; Zentel, R. Adv: Funct. Mater. 2007, 17, 109 .

11. Chang, J. Y.; Nam, S. W.; Hong, C. G.; Im, J.-H.; Kim, J.-H.; Han, M. J. Adv. Mater, 2001, 13, 1298 .

12. Nam, S. W,; Kang, S. H.; Chang, J. Y. Macromol. Res. 2007, 15, 74.

13. Cho, H. J.; Seo, K.; Lee, C. J.; Yun, H.; Chang, J. Y. J. Mater. Chem. 2003, 13,986.

14. Lee, C. J.; Lee, S. J.; Chang, J. Y. Tetrahedron Lett. 2002, 43, 3863 .

15. Hwang, I. H.; Lee, S. J.; Chang, J. Y. J. Polym. Sci, Polym. Chem. Ed. 2003, 41, 1881 .

16. Chang. J. Y;; Baik, J. H.; Lee, C. B.; Han, M. J.; Hong, S.-K. J. An. Chent. Soc. 1997, 119, 3197.

17. Chang. J. Y.; Yeon, J. R.; Shin, Y. S.; Han, M. J.; Hong, S.-K. Chem. Mater, 2000, 12, 1076. 